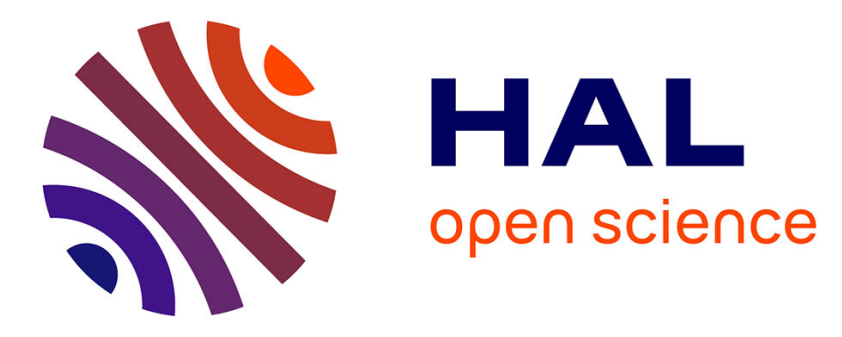

\title{
Panarchy of an indigenous agroecosystem in the globalized market: The quinoa production in the Bolivian Altiplano
}

\author{
Thierry Winkel, Pierre Bommel, Marco Chevarría-Lazo, Geneviève Cortes, \\ Carmen Del Castillo, Pierre Gasselin, François Léger, Juan-Peter Nina-Laura, \\ Serge Rambal, Muriel 46 Tichit, et al.
}

\section{To cite this version:}

Thierry Winkel, Pierre Bommel, Marco Chevarría-Lazo, Geneviève Cortes, Carmen Del Castillo, et al.. Panarchy of an indigenous agroecosystem in the globalized market: The quinoa production in the Bolivian Altiplano. Global Environmental Change, 2016, 39, pp.195-204. 10.1016/j.gloenvcha.2016.05.007 . ird-02381086

\section{HAL Id: ird-02381086 \\ https://hal.ird.fr/ird-02381086}

Submitted on 27 Nov 2019

HAL is a multi-disciplinary open access archive for the deposit and dissemination of scientific research documents, whether they are published or not. The documents may come from teaching and research institutions in France or abroad, or from public or private research centers.
L'archive ouverte pluridisciplinaire HAL, est destinée au dépôt et à la diffusion de documents scientifiques de niveau recherche, publiés ou non, émanant des établissements d'enseignement et de recherche français ou étrangers, des laboratoires publics ou privés. 


\section{Panarchy of an indigenous agroecosystem in the globalized market: the quinoa}

production in the Bolivian Altiplano

44

60

62

Thierry Winkela, ${ }^{a, *}$, Pierre Bommel ${ }^{b}$, Marco Chevarría-Lazoc ${ }^{c}$, Geneviève Cortes ${ }^{d}$, Carmen Del Castillo $^{e}$, Pierre Gasselin ${ }^{f}$, François Léger ${ }^{g}$, Juan-Peter Nina-Laura ${ }^{h}$, Serge Rambali,j, Muriel Tichitg $^{\mathrm{g}}$, Jean-François Tourrand ${ }^{\mathrm{b}}$, Jean-Joinville Vacher ${ }^{\mathrm{k}}$, Anaïs Vassas-Toral ${ }^{\mathrm{d}}$, Manuela

\section{Vieira-Pak ${ }^{b}$, Richard Joffre ${ }^{i}$}

aIRD, UMR 5175 CEFE, CNRS UM UPVM3 EPHE IRD, Montpellier, France; ' $C$ CIRAD, UPR GREEN, Montpellier, France; ' INRA, UMR MONA, Ivry-sur-Seine, France; dUniversité Paul Valéry, UMR 5281 ART-DEV, Montpellier, France; eFacultad de Agronomía, Universidad Mayor de San Andrés, La Paz, Bolivia; fINRA, UMR 951 Innovation, Montpellier, France; gUMR SADAPT, INRA, AgroParisTech,

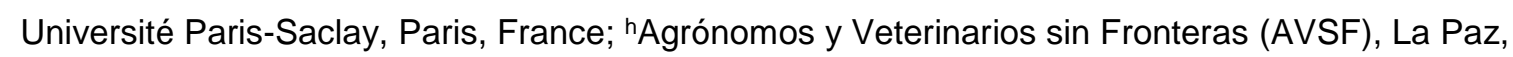
Bolivia; 'CNRS, UMR 5175 CEFE, CNRS UM UPVM3 EPHE IRD, Montpellier, France; iDepartamento de Biologia, Universidade Federal de Lavras, Lavras, MG, Brazil; kIRD, UMR 208 PALOC, IRD MNHN, Paris, France

* Corresponding author. Tel +33 467613328

\section{Citation}

Winkel T, Bommel P, Chevarría-Lazo M, Cortes G, Del Castillo C, Gasselin P, Léger F, NinaLaura JP, Rambal S, Tichit M, Tourrand JF, Vacher JJ, Vassas-Toral A, Vieira-Pak M, Joffre R. 2016. Panarchy of an indigenous agroecosystem in the globalized market: the quinoa production in the Bolivian Altiplano. Global Environmental Change 39: 195-204. URL:

https://doi.org/10.1016/i.gloenvcha.2016.05.007

\section{Acknowledgements}

This work was supported by the ANR (French National Research Agency) (ANR-06-PADD-011EQUECO). M. Vieira-Pak benefited from an international grant of the McKnight Foundation (Programa Colaborativo de Investigación de Cultivos, CCRP-Andes-2011). We express our sincere gratitude to all the people, community authorities, agencies, and students who contributed to this project in Bolivia. Special thanks are due to the Programa de Investigación Estratégica en Bolivia (PIEB) for its valuable collaboration. Thanks are extended to the platform " Systèmes d'Information en Écologie" (CEFE) for assistance in remote sensing data analyses, and to Yvette Perfecto and Doyle McKey for helpful comments on early drafts of this work. 


\section{Abstract}

Agricultural globalization is blamed for destructive impacts on small farms in developing countries. Yet, many local societies are proactive in the face of these changes and show high adaptive capacity. Investigating their transformations with an integrative perspective and enough hindsight may reveal some of the bases of their resilience and adaptive capacity. Using field data and the panarchy concept of resilience theory, we analyzed the territorial and social dynamics of quinoa growers' communities in southern Bolivia over the last four decades, a case study of regime shift in a poverty-stricken rural society which deliberately entered the global food market. Linking the dynamics of the household economy to the territorial and social subsystems over several decades, we gained insights into the interactions that shaped the rise of quinoa production in the region. We found that a vivid tradition of mobility allowing for pluriactivity on- and off-farm, combined with community self-governance, explains how local populations succeeded in articulating individual agency with collective control over their commons of land, seed resources, and social rules. Our vulnerability analysis points to landscape homogenization, social inequity, and increased dependence on external factors as potential sources of unsustainability. We conclude that, to cope with the changes of unprecedented magnitude they are facing, local producers should retain social cohesion and autonomous governance, without giving up on their heritage of mobility and economic redundancy. As regards theory, we identified cross-scale subsystem configurations critical for regime shifts, and confirm the value of panarchy in capturing complex socioecological dynamics.

\section{Keywords}

100 adaptive cycle - integrated assessment - land use change - rural livelihood strategies transformative change

\section{Highlights}

- Rural societies in developing countries are not passive in the face of agricultural globalization.

- Hindsight and interdisciplinarity enlighten the bases of their proactivity and sustainability.

- We reconstructed the socioecological panarchy of Bolivian quinoa growers since 1970s.

- Commons governance and off-farm pluriactivity are critical to control latent unsustainability.

- Particular panarchy configurations give early-warning indicators for critical regime shifts. 


\section{Introduction}

Quinoa is part of the diet of Andean populations for about 7000 years and has recently become a dietetic, organic, and gourmet commodity for Northern consumers (Bazile et al., 2015; Hellin and Higman, 2003). Family farmers of the southern Bolivian Altiplano initiated this change 40 y ago, but are now worried about the sustainability of their production. Soil erosion, biodiversity loss, and dietary degradation of local populations are pointed by development agents, researchers, and journalists, sometime using simplistic arguments and promoting questionable solutions (Winkel et al., 2012). A simple media campaign alerting consumers to emerging risks-be they real or not-could cause an immediate loss of income for local growers, and social and natural capital could be lost for rural Altiplano communities. Still, quinoa growers are quite efficient farmers and traders: producing a grain considered of little economic value until recently, they have succeeded in selling it, firstly to the neighboring market of Peru, and then to the international market in high-quality specialty foods (Giuliani et al., 2012; Laguna, 2011; Rojas et al., 2004). Their increasing efficiency was achieved by innovations such as partial crop mechanization or the incorporation in certified food-chains, combined with their traditional risk-coping strategy of mobility and off-farm pluriactivity (Kerssen, 2015; Padulosi et al., 2014; Walsh-Dilley, 2013). In fact, although quinoa growers produce for highly specialized export markets, they are not specialist farmers and are not even permanent dwellers in production areas. This is only one of the paradoxes that characterize quinoa production in this region. An agriculture booming under an extremely harsh environment, an organic and fair-trade production potentially threatening the local socioecosystem, and an opportunistic market searching for regulation: as will be detailed below, quinoa production is in many ways paradoxical.

Paradoxes reveal the complexity of reality, and sustainability science could benefit from analyzing and conceptualizing such situations to foster debates on its bases, methods, and goals, including political action and ethical controversies (Clark, 2007; Clark and Dickson, 2003; Müller, 2003; O'Connor, 2006; Vucetich and Nelson, 2010). Complexity is inherent to any human-environment interaction that includes various domains (ecological, social, economic, and cultural), scales (temporal and spatial), and goals (growth, equilibrium, or reduction) (Kajikawa, 2008). The concepts of adaptive cycles and panarchy help summarize part of this complexity. Adaptive cycles model living systems dynamics into successive phases of growth (or exploitation), conservation (or maturity), release (or collapse), and reorganization (or recycling) (Holling, 1973, 2001). Going a step further, panarchy models identify cross-scale interactions within nested hierarchies of adaptive cycles (Gunderson and Holling, 2002; Walker and Salt, 2006). These conceptual frameworks are powerful for articulating the complex structure of socioecosystems to their dynamics, transformability, and sustainability. They are relevant for many agricultural systems which show resilience in spite of harsh environment, weak rural policies, and low control of local stakeholders over foreign markets (Darnhofer et al., 2010; Darnhofer et al., 2016; Fraser and Stringer, 2009; Petrosillo et al., 2010; Salvia and Quaranta, 2015; Slaymaker, 2007).

This paper takes quinoa production in the Bolivian Altiplano as a test case to determine if adaptive cycle and panarchy models have empirical relevance for real sustainability issues. More specifically we seek to: (i) examine whether sustainability frameworks can yield insights into the paradoxes of an 
ancestral food production recently entered into the globalized food market; (ii) identify emergent lessons for local management and policy in the world's major area of quinoa exportation; and (iii) identify scientific issues relevant for research on panarchy and sustainability.

\section{Study area and theoretical backgrounds}

\subsection{Paradoxes, context, and drivers of quinoa success}

Although quinoa is a specialized and highly valued export commodity, it is produced by part-time farmers frequently absent from the production areas. The rise in quinoa production triggered many emigrant people to return seasonally to their natal rural community for plowing, sowing and harvest. Here lies a major specificity of the social system sustaining quinoa production: local populations have high mobility and perform multiple farm- and non-farm activities in their originating rural communities and regional urban centers, respectively (Vassas-Toral, 2015c).

The natural environment in this region supports a flourishing export agriculture despite poor soils, cold desert climate, and high altitude. Crop lands, located 3,650-4,200 meters above sea level, receive an annual rainfall of 150-300 mm (regional south-north gradient), with frost on more than 200 days per year (Geerts et al., 2006; Pouteau et al., 2011). This harsh environment makes quinoa nearly the sole option for cropping. Regardless of its drought tolerance (Winkel et al., 2002), quinoa is unable to complete its growing cycle in that region with only the mean annual precipitation. Therefore, quinoa is grown in a 2-yr cycle (Joffre and Acho, 2008). After harvest, the land is left unseeded for a year but plowed so that the rainfall partly accumulates in the soil and becomes a water reserve available for the following year's crop (Giuliani et al., 2012)(Supplementary Material A). To our knowledge, quinoa is the only cash crop produced under low-input rainfed agriculture in extremely high, cold, and arid mountains.

Another paradox of quinoa is its status as a health food produced in small farms mostly under organic and fair-trade certification, but that might generate ecological and social ruptures. This would be opposite to the benefits expected from low-input organic agriculture in rural societies cultivating communal land supposedly governed by ancestral rules and traditional ecological knowledge. Researchers and journalists have blamed local growers for short-sightedness and individualism, but often with ill-founded arguments (Jacobsen, 2011; Winkel et al., 2014; Winkel et al., 2012). In fact, Bolivian farmers and decision makers are well aware of the rising vulnerability of their agroecosystem (Kerssen, 2015). Local and individual initiatives at the origin of the expansion of the crop now seek collective regulations involving local authorities, growers' unions, rural development agencies, the central government, and international food industries. Moreover, and contrary to the common situation of rural poor excluded from their own natural capital (De Schutter, 2011; Kajikawa, 2008), Bolivian quinoa growers fully control access to their land resources and own on-farm selected seeds (BaudoinFarah, 2009), and take opportunistic advantage of global trends in food demand.

\subsection{Adaptive cycles and panarchy}

Adaptive cycles model the dynamics of a living system into successive phases of growth or 
renewal (Holling, 1973, 2001) (Fig. 1A). Cycle speed and amplitude are controlled by two system properties: connectedness (or degree of organization) and potential (or amount of resources). Connectedness and potential are defined depending on the ecological, economic, or sociocultural specificities of the considered adaptive cycle. Novelty in adaptive cycles may appear by the end of the reorganization ( $\alpha$ ) phase, when low internal control (low connectedness) allows for external opportunities (or "chance events") to nucleate and open unexpected options for a new growth phase. Adaptive cycles should not be seen as 4-phase sequences "repeating themselves over history" (Bunce et al., 2009): depending on the adaptive capacity of the system, transitions may occur between virtually all phases (Walker and Salt, 2006). To avoid the deterministic connotation of the term "cycle", we adopt hereafter the expression "adaptive loop" used by various authors (e.g. Delcourt and Delcourt, 2004; Marsh, 2016).

A complete panarchy model emerges when a nested hierarchy of adaptive loops is identified and cross-scale interactions are recognized (Gunderson and Holling, 2002; Walker and Salt, 2006) (Fig. 1B). A special case of cross-scale interaction, called "revolt" connection, occurs when a small-scale subsystem enters the $\Omega$ phase while the surrounding system is in late $\mathrm{K}$ phase (intermediate loop in Fig. 1B). This uniform and rigid intermediate-scale system is vulnerable to the propagation of a subsystem collapse ("revolt" arrow from the lower-scale subsystem at $\Omega$ ) which may trigger a major

206 catastrophic event. A typical example of such dynamics is the propagation of a local, small-scale fire (an $\Omega$ release phase) within a monospecific and even-aged forest in an advanced $\mathrm{K}$ phase. The renewal of the intermediate-scale subsystem will depend on the resources stored at the upper-scale subsystem ("remember" arrow). Typically, the recovery of a burned area will draw upon the seed bank and the surviving species present in the surrounding territory.

\section{Methods}

To gain insights into the social and ecological drivers of the agricultural sustainability in the world's leading area of quinoa production, a research-action project was implemented from 2007 to 2010 in rural communities of the departments of Potosi and Oruro in the southern Altiplano of Bolivia. This participative multidisciplinary research involved specialists in agroecology, agronomy, geography, and socioeconomics, with quinoa grower families and local stakeholders (workers in development agencies, quinoa growers' unions, local authorities, etc.). The results of this sustainability assessment

218 are detailed in Vassas-Toral (2015c), Vieira-Pak (2015) and Winkel et al. (2015), and only relevant information will be retained here.

\subsection{Socioeconomic surveys}

The patterns of mobility and pluriactivity among quinoa growers from the study area were characterized in a socioeconomic survey conducted in 2007 and 2008 on 149 households from five rural communities (San Juan, Chilalo, Otuyo, Candelaria, Palaya). Using interviews and livelihood stories, we retraced the residential and professional trajectories of 170 members of quinoa grower families (Supplementary Material B). Different types of spatial mobilities were considered: (i) the migration of individuals, defined as a temporary o permanent change of residence, including mobility of bi-residential migrants, (ii) the seasonal and circular mobility of migrants linked to the agricultural 
activity in their community. Collected data were structured by mapping the successive residencies of each surveyed individual, and retracing the chronology of his/her life sequences (see Vassas-Toral, $2015 \mathrm{abc}$, for detailed results). A second survey using semi-directive interviews was conducted in 2007 on 36 households from six communities (Buena Vista, Chacoma, Chilalo, Jirira, Playa Verde

232 Murmuntani, San Agustin) focusing on the household economy and the farming practices of quinoa growers (see Acosta-Alba, (2007) for detailed results).

\subsection{Land use mapping}

Cropland expansion in the last five decades was mapped on a sample of six communities representative of quinoa production in the study area, with altitudes ranging from 3700 to 4100 masl, at distances from the shores of the Salar of Uyuni varying from 2 to $40 \mathrm{~km}$ (Supplementary Material C). Some localities are mostly flat plains (Otuyo, Candelaria), while others are mostly sloping (Chilalo) or with mixed plain/slope landscapes (Capura, Chacoma, Palaya).

Cropland mapping was based on aerial photographs and high-resolution satellite images. Early panchromatic aerial photographs (Instituto Geográfico Militar, Bolivia) taken from 1961 to 1963 show

242 the croplands before the quinoa crop expansion. EROS satellite images (United States Geological Survey, USA) dated from 27/04/1972 coincide with the initial phase of quinoa expansion in the Salar

244 region. SPOT satellite images (Centre National d'Études Spatiales, France) taken between 2005 and 2008 show the phase of fast expansion of the quinoa crop. After digitalization, the ground resolution of the aerial photographs was $2 \mathrm{~m}$. Satellite images had a ground resolution of $10 \mathrm{~m}$ for EROS data, and 20 to $28.5 \mathrm{~m}$ for SPOT (depending of the year of acquisition). Image distorsions due to the sensors and the uneven ground surface were rectified using a digital elevation model (SRTM 90m). All the images were georeferenced in the UTM 19 S projection, with the datum Provisional South American

2501956 mean. Croplands were identified visually in the images as polygons of bare soil areas, clearly differentiated from the steppic vegetation of the surrounding pastures and non-agricultural land. After extraction with the ENVI 4.2 software, the cropland polygons identified were superimposed to a digital elevation model with a 20-m resolution using the ArcGIS/ArcView software. This allowed examining the altitudinal distribution of crop areas in each community, as well as their temporal changes across successive images.

\subsection{Vulnerability assessment}

Sustainability science needs vulnerability assessments integrating the human and environmental components of socioecosystems. The "vulnerability scoping diagram" presented by Polsky et al. (2007) provides multidisciplinary research teams with a common framework for organizing dissimilar information about the three dimensions of vulnerability in human-environment systems exposed to hazards, namely: exposure, sensitivity and adaptive capacity (Polsky et al., 2007; Turner II et al., 2003). We used this conceptual diagram as a guide for the collection of data, the definition of indicators and the specification of a set of hazards and outcomes relevant for quinoa production in the study area (Supplementary Material D).

\section{Results and discussion}




\subsection{Vulnerability assessment of southern Altiplano agriculture}

Our multidisciplinary research in the Bolivian Altiplano identified quinoa field expansion as the major indicator of environmental change in the study area (Winkel et al., 2015). Quantitative mapping of six communities shows that total cropland area from 1963 to 2006 increased by $332 \%$, mostly in flat plains suitable for mechanization (Fig. 2). National statistics show that the total quinoa crop area in Bolivia jumped from approximately 22,600 ha in 1963 to 42,431 ha in 2006, and 173,960 ha in 2014

272 (FAOSTAT, 2016). Quinoa yield variations and inequity in household incomes provide further vulnerability indicators. A socioeconomic survey of 36 households in 2007 revealed two consequences of the recent land use changes: (i) mean areas ( \pm CV\%) of individual quinoa fields increased from 3.1 ha $\pm 4 \%$ on slopes, to $9.3 \mathrm{ha} \pm 39 \%$ in plains; and (ii) mean quinoa yield ( $\pm \mathrm{CV}$ ) decreased from 0.91

$276 \mathrm{t} \cdot \mathrm{ha}^{-1} \pm 13 \%$ on manually cultivated slopes to $0.60 \mathrm{t} \cdot \mathrm{ha}^{-1} \pm 13 \%$ on mechanically cultivated plains. The increased CV in field area reflects a growing inequity among growers. Wealthy growers and tractor owners capture and cultivate much larger land areas than poor growers. This growing inequity affects household monetary incomes, which ranged from 200-18,000 US\$ per year among the 36 surveyed families. Independent studies report similar socioeconomic changes (Astudillo and Aroni, 2012; Félix and Villca, 2009; Kerssen, 2015; Ormachea and Ramirez, 2013). The grain yield decrease reflects the sensitivity of quinoa production to mechanized cropping in plains. Soil overexploitation has been claimed as the cause of reduced yield (Félix and Villca, 2009; Jacobsen, 2011). However, other causes could include poor seed germination in mechanically sowed fields, increased frost risks in lowlands, and pest proliferation in large monocultures. These and other ecological and social indicators of the local agroecosystem show its vulnerability to recent land use and crop management changes. Still, quinoa growers adaptively respond to new market opportunities, and display commitment to diversified livelihood strategies, despite the unprecedented success of the global quinoa market (Kerssen, 2015; Vassas-Toral, 2015c; Walsh-Dilley, 2013).

290 Grasping the ins and outs of the ongoing mutation of the quinoa socioecosystem requires adding to this static review a dynamic scaling of the structures and processes driving the system. To this end, recent changes in social context, household economy, and territorial patterns, were plotted in adaptive loop models, and we analyzed where the growth, conservation, release and reorganization phases of

294 the adaptive loops fit these changes.

\subsection{Adaptive loops in the southern Bolivian Altiplano}

\subsubsection{Social subsystem}

Historically, human demography in this highland region has been characterized by pendular migrations to nearby Andean valleys or to the Pacific coast to exchange salt and agricultural goods or to temporarily escape severe drought or frost in the Altiplano (Murra, 1984). Cycles of prosperity and collapse in Bolivian and Chilean mining industries since the $19^{\text {th }}$ century also contributed to population movements in the region (Platt, 1995). From 1950 onward, distant cities attracted ever more people in search of job opportunities and new lifestyles (Vassas-Toral, 2015c; Walsh-Dilley, 2013). Yet, the most recent Bolivian census (2012) shows an incipient repopulation dynamics, suggesting a possible re-peasantization of the southern Altiplano (Kerssen, 2015). At the same time, conflicts concerning 
land access are proliferating in the communities because migrants with double residency in the city and the community claim land access rights inherited from their parents (Supplementary Material B). The national census registers these migrants in the community, which allows them to reaffirm local land rights. These migrations are generally seasonal or temporary, and quantifying whether rural communities are effectively regaining population or undergoing a demographic decline remains a complex issue (Laguna, 2011; Vassas-Toral, 2015c).

Regulations intended to guide local land access and use are also complex and ambiguous. The 1952 agrarian reform had little impact in this inhospitable region neglected by great landlords (Laguna, 2011; Walsh-Dilley, 2013), and a multiplicity of rules have subsequently piled up. Local rules and

314 customs transmitted and controlled by traditional indigenous authorities co-exist with national laws enacted by the central government. As regards crop production, collective norms resulting from local consensus compete with food industry controls, foreign trade regulations, and intellectual property rights on quinoa varieties. Most of these rules are not uniformly applied in the region due to low rates of acceptance and lack of practical implementation. Some development agencies designate this plethora of non-uniform regulations as a "legal vacuum" (Félix and Villca, 2009). Thus, plotting population demography and social regulations as the respective potential and connectedness axes of the social adaptive loop in the region (Fig. 3A), the current situation appears to be a long-lasting reorganization $(\alpha)$ phase, with emigrants temporarily mixing with returning people, and with mixed rules of land management still not implemented. Notably, reorganization does not occur here after a collapse $(\Omega)$ phase of ancient local societies, but rather as progressive adjustments of their population dynamics and land management rules.

\subsubsection{Household subsystem}

Amid this varying social framework, the quinoa economy has flourished rapidly in the region. Quinoa as a cash crop expanded during 1970-1980 from the southern border to the western and northern borders of the Salar of Uyuni. This expansion was initiated in response to: i) massive job cuts in the mining and public sectors due to structural adjustment plans, ii) increasing demand for quinoa in neighboring Peru, a country much more populated than Bolivia and where urban consumers appreciated quinoa, which was not the case in Bolivia at that time. In 1970, a Belgian development aid program donated tractors to local, poor communities, a case of "chance event" which favored that initial phase of commercial production for the national and Peruvian markets (Kerssen, 2015; Laguna, 2011). In the mid 1980's, Bolivian quinoa growers opportunistically responded to new, increased demand from North America and Europe for gluten-free, protein-rich, organic food, often under fairtrade label. These new markets did not supplant the Peruvian market, which accounted for up to $40 \%$ of total Bolivian quinoa exports by the 2000's, though mostly as unofficial trade (Gandarillas et al., 2015; Laguna, 2002; Laguna, 2011; Rojas, 2011). Thus, local quinoa growers beneficially serve a diversity of quinoa market niches. Yet, this success did not spur them to fully specialize in quinoa production. The vast majority maintain off-farm activities and temporary migration (Supplementary

342 Material B: Table B-1 and reported individual cases), with a few even keeping on with llama and sheep rearing, despite lower economic profitability. Diversified household trajectories result from this redundancy in more or less rewarding activities involving different family members (Laguna, 2002; 
Vassas-Toral, 2015c). This risk-coping strategy may prove to be useful under the market distortions observed since 2014, when Peru began to supplant Bolivia in the international quinoa market (Mercadero, 2015). If the household economic loop is plotted with quinoa income and market connection as the potential and connectedness axes respectively (Fig. 3B), then quinoa growers of the southern Bolivian Altiplano appear to follow multiple trajectories between the growth $(r)$ and conservation $(K)$ phases, resolutely engaged in commercial production but avoiding connecting their household activities exclusively to that opportunistic venture. Partial back loops exist, and moving from one trajectory to another is relatively easy (Vassas-Toral, 2015c; Vieira-Pak, 2015). For example, if a quinoa grower opted for the specialized certified market, he can easily move to the less constraining and almost equally rewarding conventional market, or may choose to invest more effort in off-farm activities (Ofstehage, 2012). However, achieving this flexibility is not easy for the poorest households (single mothers or elderly single people) due to the lack of human and financial capital. The current variety of household trajectories also reflects past social and economic disparities, which are exacerbated by quinoa commercialization (Vassas-Toral, 2015c; Vieira-Pak, 2015).

\subsubsection{Territorial subsystem}

This subsystem appears more constrained than the household subsystem. A single quinoa harvest is the product of a 2-year cycle and, thus, represents a doubled land area: the current cultivated field, plus the plowed fallow waiting for the next year's crop (Supplementary Material A). Quinoa expansion pushed herbaceous and shrub species to marginal lands. These wild plants hardly recolonize the fallow due to their slow dynamics and the depletion of soil seed banks (Joffre and Acho, 2008). Conversion of pastures into quinoa fields thus results in an essentially irreversible change in land use, with a striking loss of landscape patchiness. Bare fallows are exposed to strong and frequent windstorms. The newly converted quinoa fields are mostly located in flat lowlands prone to frost due to cold air drainage at night (Pouteau et al., 2011). Frost events in 2007 and 2008 revealed the vulnerability of lowland production with 2008 referred to as a tipping point in the quinoa market (Núñez de Arco, 2015). Production was low due to these frost events but commercial demand remained high, which caused the quinoa price to increase by 175\% from 2006 to 2008 (Gabriel, 2013). These high prices encouraged farmers to continue taking the risk of cultivating quinoa in the lowlands.

Most of the areas apt for mechanized cropping have already been converted into quinoa fields, and many communities can no longer respond to the continuing demand for new croplands. A decline of soil fertility in the region has been denounced (Félix and Villca, 2009; Jacobsen, 2011), allegedly

376 showing that the ecosystem's carrying capacity has been exceeded. However, this opinion has not been corroborated by any in situ study, and the evidence used to support it consists of gross regional or national grain yield statistics, which mix concomitant effects of climate, soil, pests, and poor seed germination in mechanized crops (Walsh-Dilley, 2013; Winkel et al., 2012). While soil degradation remains debatable, land conversion to quinoa cropping thus appears as the most reliable indicator of the ecosystem's carrying capacity reaching an upper limit. Land conversion resulted from the decision of local producers to favour quinoa at the expense of the economically less-rewarding components of their agricultural system, namely pastures and potato crops (Laguna, 2011; Walsh-Dilley, 2013). After a sustained growth phase $(r)$, the territorial adaptive loop appears locked into an ending conservation 
phase $(K)$ with contiguous quinoa monocultures resulting in minimum landscape patchiness (maximum field connectedness, $x$-axis), and the maximum available land area (natural capital, $y$-axis) already converted to cropland in most communities (Fig. 3C).

\subsection{Panarchy of the quinoa's rise}

\subsubsection{Nested adaptive loops}

A hierarchy linking the adaptive loops for social, household, and territorial subsystems is organized with respect to time and population scales (Fig. 4). The household loop occupies the lower scales since it primarily refers to individual decisions regarding annual on-farm and off-farm activities. Typically, household dynamics occur on a 1- to 6-month scale, e.g. to choose temporary migration or which parcel to plow. The territorial loop is located at the larger landscape scale, with a minimum 2year cycle for field crop, and a grossly decadal dynamics for land use changes and natural vegetation regeneration. Next, the social loop operates from the community to the nation and from decadal to multidecadal periods corresponding to background demographic trends and land access/land use regulations. Demographic and institutional changes commonly show slower dynamics than do ecological changes (Young, 2010). In fact, the social loop could be extended up to the global level, as the current international market directly affect the local agrarian dynamics through the commercial demand and trade regulations (Gabriel, 2013; Giuliani et al., 2012; Rojas, 2011).

The phases currently reached by each adaptive loop show that the territorial component is locked in a potentially vulnerable conservation phase $(K)$ between household and social loops (Fig. 4B). Yet,

404 a "revolt" connection (see Fig. 1B) amplified by this broad-scale vulnerability seems unlikely, as the lower-scale household economic loop is far from the release phase $(\Omega)$. The diversified household livehood strategies, associated to rural-urban mobility (Supplementary Material B) (Laguna, 2011; Vassas-Toral, 2015c) prevent any locking into a specialized commodity chain. If commodity chains were to experience sudden collapse, it would trigger the abandonment of croplands-a release phase $\Omega$ in the territorial adaptive loop_-but without catastrophic impact on households which opportunistically maintain their economies between growth $(r)$ and conservation $(K)$ extremes by repeated migration and shifting between farm- and non-farm activities (Fig. 3B).

412 Because the trajectories of many agroecosystems lack of certain phases or appear stuck in particular stages of the adaptive loop, some authors call into question the usefulness of Holling's

414 model in resilience studies (Bunce et al., 2009). Also, it has been argued that Gunderson and Holling's theory is more adequate to describe ecological processes than to capture adaptive responses related 416 to human decisions (Fraser and Stringer, 2009). Both critiques should be relativized since: i) adaptive loops are not deterministic 4-phase sequences: the panarchy theory states that alternative paths and

418 shortcuts might occur within adaptive loops, some of which open the way towards resilience (Gunderson and Holling, 2002; Walker and Salt, 2006); besides, stagnation in one adaptive loop of the system does not impede rapid changes in other components, as found comparing the social subsystem to the other two components in our case study; ii) in agroecosystems in particular, alternative paths of resilience depend strongly on human decisions: our analysis of quinoa growers' strategies demonstrates that these decisions are adequately captured by an adaptive loop model. 
Thus, contrary to the suggestion of Fraser and Stringer (2009), it seems not justified to restrain the panarchy approach to the environmental component of the socio-ecosystem. In fact, the main interest of the panarchy theory lies in its capacity to encompass environmental as well as social, economic, and institutional dynamics: disaggregating the environmental and human components of change may be necessary in an early phase of analytical assessment but then, ordering them across nested hierarchies to reveal their interdependencies is what makes the value of this transdisciplinary and relational approach (Darnhofer et al., 2016; Kajikawa, 2008; Scholz and Steiner, 2015; Sundstrom et al., 2014).

\subsubsection{Retroactive search for causalities}

A retroactive examination of quinoa panarchy can provide insight into recent events (Westley, 2002) and identify circumstances, actors, and organizations that shaped the historical development of quinoa production in southern Bolivia. At the end of the 1960s, crop production and pastoralism provided low income due to the lack of markets, conducing a growing part of the local population to frequent and prolonged migration to cities and other countries in search of non-farm activities. Thus, 438 the territorial and household subsystems were in a reorganization $(\alpha)$ phase but with still uncertain prospects as regards local development (Fig. 4A). The declining rural population was ageing, which caused local institutions and social rules to lose vitality. The social subsystem found itself caught between collapse $(\Omega)$ and reorganization $(\alpha)$ phases (Fig. 4A). The wealthiest among the permanent rural dwellers were those who owned a substantial number of sheep and llamas and had greatest access to communal pastures. Rural migrants with savings from off-farm activities were also in a

444 favorable position to assert land usufruct rights which families always retain in their natal communities. Both categories of households had the potential to invest capital in new economic activities. As regards the territorial land resources at that time, there was little competition for land access and little control on land use due to the low interest in farming activities. In 1970, these circumstances enabled some indivi duals to respond opportunistically to newly available tractors and the continuous Peruvian demand for quinoa. New quinoa fields were opened in common pastures in flat lowlands, easily mecanizable, lacking individual property rights, and considered of little value. The social, territorial, and household subsystems were then positioned in similar reorganization $(\alpha)$ phases, ready to produce a cascade of new patterns across the hierarchy of adaptive loops_-viz the panarchy-of the local quinoa production (Fig. 4A, dashed line). In the following years, however, the dynamics of the

454 three adaptive loops rapidly diverged. This led to the present situation (Fig. 4B) with multiple household activities and adjustments (loop $\mathrm{E}$ between $r$ and $K$ ), maximum pressure on land resources

456 (loop T near $K$ ), and prolonged experimentation and uncertainty in social and institutional issues (loop S near $\alpha)$.

\subsection{Lessons for local development}

The rise of quinoa production in southern Bolivia began 40 years ago. Large changes have occurred in society, agrotechnology, and economics which preclude a mere return to traditional agricultural models. The transition from ancestal manual cropping to mechanized cropping exemplifies 
change. As in other rural societies in the Andes (Lennox and Gowdy, 2014; Zimmerer, 2013), new challenges regarding land management have emerged, which require new visions for a sustainable future.

Panarchy highlights the importance of individual initiatives for adaptability of quinoa growers. Mobility and pluriactivity are key components of the household's functional redundancy, a concept that date back to an ancestral economic mobility (Núñez Atencio and Hall, 1982; Saignes, 1995), and has been adjusted to current technical and trading innovations. With a singularity however: for the first time in centuries, local agriculture is an economically attractive enterprise, which stimulates seasonal returns of migrants to their natal communities (Walsh-Dilley, 2013). Since growing quinoa entails a

472 hereditary access to communal land, it enables autonomy to local populations, which is radically different from selling their labor force in cities or mining industries. This change was quickly assimilated by rural dwellers who then adopted a patrimonial logic and tried to hoard the largest possible cropland area, within the bounds of the customary land tenure rules. This quantitative 476 patrimonialization rapidly reached the limits of available space, and a qualitative patrimonialization is now needed to improve cropping practices, and negotiate comprehensive agreements for using common land resources.

Thus far, the social system also contributed to changes in quinoa production, though in an ambiguous way. Heirs of a tradition of self-governance and rotating public responsibilities, local authorities and quinoa growers' unions did not exert any strong social control on their own members until recently. This behavior enabled the free transformation of an agroecosystem with manual cropping and long fallows to mechanized monocultures and short fallows. The prevalence of oral rules during the early transformation may have promoted these changes. Ambiguity in the social control system also appears to be part of a logic of the local institutions to avoid contradictory commitments to the traditional subsistence system and the market-oriented system. Rivalry between local authorities and quinoa growers' unions could emerge, the latter relaying the top-down market demand for 488 international norms of sustainable production, and the former engaging in a bottom-up renovation of local ancestral rules governing their commons. Both adaptability and transformability are essential for resilience (Walker and Salt, 2006). In the southern Bolivian Altiplano, the household adaptability and the social transformability may result in contradicting influences (see subsequent discussion on adaptation traps). These properties rely primarily on the capacity of the institutions controlling common resources to evolve by self-transformation, which requires social cooperation and commitment to avoid centralized regulation or privatization (Vollan and Ostrom, 2010).

The observed territorial vulnerability suggests a central role for the landscape structure in determining the agroclimatic risks faced by quinoa growers. Frost risks persist in the region despite climate warming trends (Pouteau et al., 2011; Rambal et al., 2015), and monocultures in vast lowland areas may worsen drought, pest outbreaks, and soil degradation. Local agronomic institutes are conducting participatory research on these issues to design innovative land management practices

500 (Bonifacio et al., 2014). Numerous communities have begun using integrated organic pest management and planting living fences against wind erosion (Lino et al., 2014). These agroecological practices promoted by farmers' unions and NGOs illustrate social learning and innovation drawn from 
local experimentations (Knight and Meffe, 1997). Pilot experiments on new payment for ecosystem 504 service schemes are another example of collective action to conserve local quinoa biodiversity (Narloch et al., 2015).

506 The southern Bolivian Altiplano socioecosystem conforms to the conditions for adaptive land management-persistency, change and uncertainty (Holling, 1973). Persistency of the local society

508 relies on mobility and flexibility of the growers' families, self-governance of their communities and organizations, and material and symbolic territorial valorization. Changes in land use and household 510 activities enable land transformation as new opportunities appear. This illustrates how local populations cope with, rather than confront, uncertainty due to fluctuations in climate or economy

512 (Walsh-Dilley, 2013). Similar synergies between off-farm migration, governance of the commons and innovation leading to social and ecological resilience have been described in smallholders

514 communities engaged in agricultural intensification in other regions of Bolivia (Zimmerer, 2013). In other Andean regions, however, the sustainability of smallholder agriculture may rely on different 516 bases, depending on local settings of land tenure, social organization, opportunities for off-farm activities and market access (Lennox and Gowdy, 2014; Padulosi et al., 2014; Sietz et al., 2012).

Although quinoa growers tried to adaptively manage their territorial resources, there are several indicators of latent unsustainability. In some communities, vast quinoa monocultures have generated conflicts over land access (Laguna, 2011; Vassas-Toral, 2015c). This partly resulted from familial and social agreements that permit families to cultivate without being present in the community. These are the same agreements that support household adaptability and territorial transformability, illustrating an adaptation trap in which incremental adjustments and economic redundancies delay local stakeholder awareness of agroecosystem vulnerabilities (van Apeldoorn et al., 2011). All stakeholders do not share the same capacity to access social and territorial resources, or to activate multiple options of economic redundancies. The poorest families with the lowest social capital also are the most disadvantaged in competition for new croplands. In this context, livelihood diversification further increases social inequity among families. An undesirable system could thus emerge in which household adaptability generates a trap that could threaten social equity and ecological sustainability.

To face such complex issues, development NGOs, state or private services offer their expertise. Indeed, the rationality of local populations is no longer the only one that applies in the Bolivian 532 altiplano: new foreign actors introduce divergent opinions and practices, which increases the quinoa socioecosystem complexity. Now, complexity also can cause unsustainability (Fisk and Kerherve, 534 2006). Some of the new foreign actors promote short-sighted interests and irreversible technological innovations like irrigation or certified seeds, with a lack of integrative vision which has great potential to worsen the situation. These actors reinforce the command-and-control approach to natural resource management (Briggs, 2003; Holling and Meffe, 1996). If this approach is followed, local societies

538 would become increasingly dependent on risky technologies, bank credits, and rationales external to the local social and environmental context. Southern Altiplano populations are fluent with foreign markets and different cultures, as part of their inherited lifestyle based on active mobility and trade exchange (Stern, 1995). Yet, the unprecedented magnitude of these emerging socioeconomic interactions raises concerns (Lennox and Gowdy, 2014). Local policy-makers and stakeholders should 
cautiously evaluate these new forms of interference and dependence before making decisions that bind the region and its inhabitants to a future they may not desire. Such a loss of autonomy would challenge the goals of good living and food sovereignty recently integrated into the Bolivian constitution (Cockburn, 2013; Kerssen, 2015; Mercado et al., 2016).

\section{Conclusion}

This study reminds us that panarchy is more than just the adaptive loop of a specific subsystem: a panarchy is essentially a dynamic hierarchy of several subsystems - environmental and human-that interact over nested scales of time and space. Using this multi-dimensional and dynamic perspective, we were able to elucidate part of the sustainability of quinoa production in the southern altiplano of Bolivia during the last four decades, firstly by identifying the characteristics of the households, the environment, and the communities at stake. Then, by examining interactions between these nested components, we found that the adhesion of local populations to self-governance and the tradition of temporary migration, instead of causing social stagnation, had indeed stimulated the rapid transformation of their territory. This is explained by processes operating at different scales: a limited social control in the initial phase of crop expansion, the interdiction for foreigners to access land resources in the communities, and household's pluriactivity as a continued risk-coping strategy despite the boon of the quinoa trade.

While nested hierarchies of scales may be relatively trivial to detect (household, community, state, etc.), their driving interactions are less obvious because the underlying dynamics often require time to develop and become apparent. Conceptual efforts should be made to enrich the typology of these interactions and discover new cross-scale connections beyond the well-described configurations of revolt or memory (Walker and Salt, 2006) (Fig. 1B). The synchronous alignment of nested subsystems in reorganization phase $(\alpha)$ found in this study is an example of such critical configurations (Fig. 4A). It reveals a situation open to innovations, chance events, and regime shifts cascading across subsystems. This alignment pattern within a complex socioecosystem may provide an early-warning indicator, a form of intrinsically cross-scale transition signal (Scheffer et al., 2009). Despite such conceptual advances, scholars and decision makers should accept that no panacea 570 exists for modeling or governing socioecosystems (Anderies and Janssen, 2013; Brock and Carpenter, 2007; Ostrom, 2007). These are controlled simultaneously by fast and slow variables, and go through incessant co-adaptation processes that continuously change their structure, function, and interrelationships, with inevitable dysfunctions (Reynolds et al., 2007; Stafford Smith et al., 2007). In

574 such systems, static equilibria never arise and top-down command-and-control governance fails (Holling and Meffe, 1996). Instead, continuous adaptive learning and polycentric governance copes with uncertainties and opportunities, particularly in agricultural or natural resource management (Anderies and Janssen, 2013; Darnhofer et al., 2010). Because panarchy models help identifying 578 people and organizations responsible for the choices and consequences of development policies, an ethical issue rises up: topics of equity, sustainability, and autonomy of local societies stem from these choices (Vucetich and Nelson, 2010), and thus challenge the social utility of scholarly research (Thompson, 2008). Agroecosystems offer fertile ground for such ethical questioning in sustainability science. 
Acosta-Alba, I., 2007. Durabilité des systèmes de production de l'altiplano sud bolivien : quels équilibres entre élevage et agriculture ? AgroParisTech, Université Paris 7, Paris, France, $44 \mathrm{p}$.

Alvarez-Flores, R., Winkel, T., Degueldre, D., Del Castillo, C., Joffre, R., 2014a. Plant growth

590 dynamics and root morphology of little-known species of Chenopodium from contrasted Andean habitats. Botany 92, 101-108. http://dx.doi.org/110.1139/cjb-2013-0224

Alvarez-Flores, R., Winkel, T., Nguyen-Thi-Truc, A., Joffre, R., 2014b. Root foraging capacity depends on root system architecture and ontogeny in seedlings of three Andean Chenopodium species. Plant and Soil 380, 415-428. http://dx.doi.org/10.1007/s11104-014-2105-x

Anderies, J.M., Janssen, M.A., 2013. Robustness of social-ecological systems: implications for public policy. Policy Studies Journal 41, 513-536. http://dx.doi.org/10.1111/psj.12027

Astudillo, D., Aroni, G., 2012. Livelihoods of quinoa producers in southern Bolivia, in: Giuliani, A., Hintermann, F., Rojas, W., Padulosi, S. (Eds.), Biodiversity of Andean grains: balancing market potential and sustainable livelihoods. Bioversity International, Rome, Italy, pp. 78-145.
600 Baudoin-Farah, A., 2009. Evaluación y perspectivas del mercado de semillas certificadas de quinua en la región del Salar de Uyuni en el Altiplano Sur de Bolivia. Master Thesis, AgroParisTech, Département SIAFEE, Paris, France, $35 \mathrm{p}$.

Bazile, D., Bertero, D., Nieto, C., 2015. State of the art report on quinoa around the world in 2013.

606

FAO (Santiago de Chile) y CIRAD, (Montpellier, Francia), Rome, Italy, 589 p. URL:

http://www.fao.org/583/a-i4042e.pdf

Bonifacio, A., Aroni, G., Villca, M., Ramos, P., Alcon, M., Gandarillas, A., 2014. The current and potential role of q'ila q'ila (Lupinus spp.) in quinoa sustainable production systems. Revista de Agricultura (Bolivia. 54, 11-18. http://www.proinpa.org/publico/REVISTA 54 INGLES.pdf

Briggs, S., 2003. Command and control in natural resource management: revisiting Holling and Meffe.

Ecological Management \& Restoration 4, 161-162. http://dx.doi.org/10.1046/j.14428903.2003.00151.x

Brock, W.A., Carpenter, S.R., 2007. Panaceas and diversification of environmental policy. Proceedings of the National Academy of Sciences of the United States of America 104, 1520615211. http://www.pnas.org/content/104/39/15206.abstract

Bunce, M., Mee, L., Rodwell, L.D., Gibb, R., 2009. Collapse and recovery in a remote small island: a tale of adaptive cycles or downward spirals? Global Environmental Change 19, 213-226. http://dx.doi.org/10.1016/i.gloenvcha.2008.11.005

Clark, W.C., 2007. Sustainability science: a room of its own. Proceedings of the National Academy of Sciences of the United States of America 104, 1737-1738.

http://dx.doi.org/10.1073/pnas.0611291104 
Clark, W.C., Dickson, N.M., 2003. Sustainability science: the emerging research program. 8061. http://dx.doi.org/10.1073/pnas.1231333100

Cockburn, J., 2013. Bolivia's food sovereignty \& agrobiodiversity: undermining the local to strengthen the state?, International Conference "Food Sovereignty: A Critical Dialogue", September 14-15, 2013, Yale University, USA. URL: https://www.tni.org/en/briefing/bolivias-food-sovereigntyagrobiodiversity.

Darnhofer, I., Bellon, S., Dedieu, B., Milestad, R., 2010. Adaptiveness to enhance the sustainability of farming systems. A review. Agronomy for Sustainable Development 30, 545-555. http://dx.doi.org/10.1051/agro/2009053

Darnhofer, I., Lamine, C., Strauss, A., Navarrete, M., 2016. The resilience of family farms: towards a relational approach. Journal of Rural Studies 44, 111-122. http://dx.doi.org/10.1016/i.jurstud.2016.01.013

De Schutter, O., 2011. The green rush: the global race for farmland and the rights of land users. Harvard International Law Journal 52, 503-559. http://www.harvardilj.org/2011/07/issue 52-2 de$\underline{\text { schutter/ }}$

Delcourt, P.A., Delcourt, H.R., 2004. Prehistoric native Americans and ecological change. Human ecosystems in Eastern North America since the pleistocene. Cambridge University Press, Cambirdge, UK.

FAOSTAT 2016. Quinoa production. Statistics Division, Food and Agriculture Organization of the United Nations, Rome, Italy. Retrieved 31/03/2016: http://faostat3.fao.org/search/*/E

Félix, D., Villca, C., 2009. Quinua y territorio: Experiencias de acompañamiento a la gestión del territorio y a la autogestión comunal en la zona Intersalar del altiplano boliviano. VSF-CICDARuralter, Lyon, France. https://www.avsf.org/public/posts/564/quinoa-y-territorio.pdf

Fisk, D.J., Kerherve, J., 2006. Complexity as a cause of unsustainability. Ecological Complexity 3 , 336-343. http://dx.doi.org/10.1016/j.ecocom.2007.02.007

Fraser, E.D.G., Stringer, L.C., 2009. Explaining agricultural collapse: macro-forces, micro-crises and the emergence of land use vulnerability in southern Romania. Global Environmental Change 19, 45-53. http://dx.doi.org/10.1016/i.gloenvcha.2008.11.001

Gabriel, A., 2013. Royal Quinoa reigning the world: from food of the poor to world's superfood. Bachelor Thesis, Van Hall Larenstein - Applied University of Science, Wageningen, The Netherlands, 80 p. http://mercadero.nl/wp-content/uploads/Final Thesis AG FTM 1.7.pdf

Gandarillas, A., Rojas, W., Bonifacio, A., Ojeda, N., 2015. Quinoa in Bolivia: the PROINPA Foundation's perspective, in: Bazile, D., Bertero, D., Nieto, C. (Eds.), State of the art report on quinoa around the world in 2013. FAO, Santiago, Chile, pp. 344-377. URL: http://www.fao.org/343/a-i4042e.pdf

Geerts, S., Raes, D., Garcia, M., Del Castillo, C., Buytaert, W., 2006. Agro-climatic suitability mapping for crop production in the Bolivian Altiplano: a case study for quinoa. Agricultural and Forest Meteorology 139, 399-412. http://dx.doi.org/10.1016/j.agrformet.2006.08.018 
Giuliani, A., Hintermann, F., Rojas, W., Padulosi, S., 2012. Biodiversity of Andean grains: balancing market potential and sustainable livelihoods. Bioversity International, Rome, Italy, 198 p. http://www.bioversityinternational.org/index.php?id=19\&user bioversitypublications pi1[showUid] $=7303$

Gunderson, L.H., Holling, C.S., 2002. Panarchy: understanding transformations in human and natural systems. Island Press, Washington (DC), USA, $507 \mathrm{p}$.

Hellin, J., Higman, S., 2003. Quinoa and food security, in: Hellin, J., Higman, S. (Eds.), Feeding the Market: South American Farmers, Trade and Globalization. Intermediate Technology Development Group (ITDG) Publishing, London, UK, pp. 131-168.

Holling, C.S., 1973. Resilience and stability of ecological systems. Annual Review of Ecology and Systematics 4, 1-23. http://dx.doi.org/10.1146/annurev.es.04.110173.000245

Holling, C.S., 2001. Understanding the complexity of economic, ecological, and social systems. Ecosystems 4, 390-405. http://dx.doi.org/10.1007/s10021-001-0101-5

Holling, C.S., Meffe, G.K., 1996. Command and control and the pathology of natural resource 1739.1996.10020328.x

Jacobsen, S.E., 2011. The situation for quinoa and its production in southern Bolivia: from economic success to environmental disaster. Journal of Agronomy and Crop Science 197, 390-399.

\section{http://dx.doi.org/10.1111/j.1439-037X.2011.00475.x}

Joffre, R., Acho, J., 2008. Quinua, descanso y tholares en el sur del Altiplano Boliviano. Hábitat 75, 38-41. http://www.lidema.org.bo/

Kajikawa, Y., 2008. Research core and framework of sustainability science. Sustainability Science 3 , 215-239. http://dx.doi.org/10.1007/s11625-008-0053-1

Kerssen, T.M., 2015. Food sovereignty and the quinoa boom: challenges to sustainable repeasantisation in the southern Altiplano of Bolivia. Third World Quarterly 36, 489-507. http://dx.doi.org/10.1080/01436597.2015.1002992

Knight, R.L., Meffe, G.K., 1997. Ecosystem management: agency liberation from command and control. Wildlife Society Bulletin 25, 676-678. http://researchlegacy.arch.tamu.edu/epsru/pdf/plan641/Plan\%20PDFs\%202/Plan\%20PDFs\%202/Knight\%20an d\%20Meffe.pdf

Laguna, P., 2002. Competitividad, externalidades e internalidades, un reto para las organizaciones económicas campesinas: la inserción de la Asociación Nacional de Productores de Quinua en el mercado mundial de la quinua. Debate Agrario (Perú) 34, 95-169. http://www.cepes.org.pe/debate/debate34/04-articulo-da34.pdf

Laguna, P., 2011. Mallas y flujos: acción colectiva, cambio social, quinua y desarrollo regional indígena en los Andes Bolivianos. School of Social Sciences, Wageningen University, Wageningen, The Netherlands, 516 p. http://edepot.wur.nl/188049

Lennox, E., Gowdy, J., 2014. Ecosystem governance in a highland village in Peru: facing the challenges of globalization and climate change. Ecosystem Services 10, 155-163. http://dx.doi.org/10.1016/j.ecoser.2014.08.007 
Lino, V., Olivera, J., Saravia, R., Quispe, R., Gandarillas, E., Crespo, L., 2014. Mass dissemination of the Integrated Pest Management (IPM) strategy for quinoa. Revista de Agricultura (Bolivia. 54, 68-72. http://www.proinpa.org/publico/REVISTA 54 INGLES.pdf

Marsh, E.J., 2016. The disappearing desert and the emergence of agropastoralism: an adaptive cycle of rapid change in the mid-Holocene Lake Titicaca Basin (Peru-Bolivia). Quaternary International, in press. http://dx.doi.org/10.1016/i.quaint.2015.12.081

Mazoyer, M., Roudart, L., 2006. A history of world agriculture from the neolithic age to the current crisis. Translated by James H. Membrez. Earthscan Publ., London, UK.

Mercadero, 2015. European quinoa market continues fast growth while prices have dropped. Mercadero, Wageningen, The Netherlands; Retrieved 2015/12/23: http://mercadero.nl/category/quinoa-market-analysis/

Mercado, G., Hjortsø, C.N., Kledal, P.R., 2016. Public procurement for school breakfasts in the Bolivian Altiplan: governance structures enabling smallholder inclusion. Journal of Rural Studies 44, 63-76. http://dx.doi.org/10.1016/j.jrurstud.2016.01.004

Müller, A., 2003. A flower in full blossom?: ecological economics at the crossroads between normal and post-normal science. Ecological Economics 45, 19-27. http://dx.doi.org/10.1016/S09218009(02)00256-2

Murra, J.V., 1984. Andean societies. Annual Review of Anthropology 13, 119-141. http://dx.doi.org/10.1146/annurev.an.13.100184.001003

Narloch, U., Drucker, A.G., Pascual, U., 2015) What role for cooperation in conservation tenders? Paying farmer groups in the High Andes. Land Use Policy, in press. http://dx.doi.org/10.1016/j.landusepol.2015.09.017

Núñez Atencio, L., Hall, H., 1982. Análisis de dieta y movilidad en un campamento arcaico del Norte de Chile. Bulletin de l'IFEA 11, 91-113. http://www.ifeanet.org/publicaciones/boletines/11\%283-

\section{4\%29/91.pdf}

Núñez de Arco, S., 2015. Quinoa's calling, in: Murphy, K.M., Mataguihan, J. (Eds.), Quinoa: Improvement and Sustainable Production. John Wiley \& Sons, Hoboken, NJ, USA, pp. 211-226.

O'Connor, M., 2006. The "Four Spheres" framework for sustainability. Ecological Complexity 3, 285292. http://dx.doi.org/10.1016/i.ecocom.2007.02.002

Ofstehage, A., 2012. The construction of an alternative quinoa economy: balancing solidarity, household needs, and profit in San Agustín, Bolivia. Agriculture and Human Values 29, 441-454. http://dx.doi.org/10.1007/s10460-012-9371-0

Ormachea, E.S., Ramirez, N.F., 2013. Propiedad colectiva de la tierra y producción agrícola capitalista: el caso de la quinua en el Altiplano Sur de Bolivia. Centro de Estudios para el Desarrollo Laboral y Agrario - CEDLA, La Paz, Bolivia. http://mercadero.nl/wpcontent/uploads/libro-quinua-2013-pdf.pdf

Ostrom, E., 2007. A diagnostic approach for going beyond panaceas. Proceedings of the National Academy of Sciences of the United States of America 104, 15181-15187. http://dx.doi.org/10.1073/pnas.0702288104 
Padulosi, S., Amaya, K., Jäger, M., Gotor, E., Rojas, W., Valdivia, R., 2014. A holistic approach to

742 enhance the use of neglected and underutilized species: the case of andean grains in Bolivia and Peru. Sustainability 6, 1283-1312. http://www.mdpi.com/2071-1050/6/3/1283

Petrosillo, I., Zaccarelli, N., Zurlini, G., 2010. Multi-scale vulnerability of natural capital in a panarchy of social-ecological landscapes. Ecological Complexity 7, 359-367.

\section{http://dx.doi.org/10.1016/i.ecocom.2010.01.001}

Platt, T., 1995. Ethnic calendars and the market interventions among the Ayllus of Lipes during the nineteenth century, in: Larson, B., Harris, O., Tandeter, E. (Eds.), Ethnicity, markets, and migration in the Andes: at the crossroads of history and anthropology. Duke University Press, Durham, USA, pp. 259-296.

Polsky, C., Neff, R., Yarnal, B., 2007. Building comparable global change vulnerability assessments: the vulnerability scoping diagram. Global Environmental Change 17, 472-485. http://dx.doi.org/10.1016/i.gloenvcha.2007.01.005

Pouteau, R., Rambal, S., Ratte, J.-P., Gogé, F., Joffre, R., Winkel, T., 2011. Downscaling MODISderived maps using GIS and boosted regression trees: the case of frost occurrence over the arid Andean highlands of Bolivia. Remote Sensing of Environment 115, 117-129. http://dx.doi.org/10.1016/..rse.2010.08.011

Rambal, S., Ratte, J.P., Mouillot, F., Winkel, T., 2015. Trends in quinoa yield over the southern Bolivian altiplano: lessons from climate and land-use projections, in: Murphy, K.M., Matanguihan, G.J. (Eds.), Quinoa Improvement and Sustainable Production. John Wiley \& Sons, Hoboken, NJ, USA, pp. 47-62.

Reynolds, J.F., Stafford Smith, D.M., Lambin, E.F., Turner II, B.L., Mortimore, M., Batterbury, S.P.J., Downing, T.E., Dowlatabadi, H., Fernández, R.J., Herrick, J.E., Huber-Sannwald, E., Jiang, H., Leemans, R., Lynam, T., Maestre, F.T., Ayarza, M., Walker, B., 2007. Global desertification: building a science for dryland development. Science 316, 847-851.

http://dx.doi.org/10.1126/science.1131634

Rojas, W., 2011. Quinoa, an ancient crop to contribute to world food security. FAO, Oficina Regional para America Latina y el Caribe, Santiago, Chile, $58 \mathrm{p}$. http://www.fao.org/fileadmin/templates/aiq2013/res/en/cultivo quinua en.pdf

Rojas, W., Soto, J.L., Carrasco, E., 2004. Study on the social, environmental and economic impacts of quinoa promotion in Bolivia. PROINPA Foundation, La Paz, Bolivia, $84 \mathrm{p}$.

Saignes, T., 1995. Indian migration and social change in seventeeth-century Charcas, in: Larson, B., Harris, O., Tandeter, E. (Eds.), Ethnicity, markets, and migration in the Andes: at the crossroads of history and anthropology. Duke University Press, Durham, USA, pp. 167-195.

Salvia, R., Quaranta, G., 2015. Adaptive cycle as a tool to select resilient patterns of rural development. Sustainability 7, 11114. http://www.mdpi.com/2071-1050/7/8/11114

Scheffer, M., Bascompte, J., Brock, W.A., Brovkin, V., Carpenter, S.R., Dakos, V., Held, H., van Nes, E.H., Rietkerk, M., Sugihara, G., 2009. Early-warning signals for critical transitions. Nature 461, 53-59. http://dx.doi.org/10.1038/nature08227 
Scholz, R.W., Steiner, G., 2015. Transdisciplinarity at the crossroads. Sustainability Science 10, 521 -

526. http://dx.doi.org/10.1007/s11625-015-0338-0

Sietz, D., Mamani Choque, S.E., Lüdeke, M.K.B., 2012. Typical patterns of smallholder vulnerability to weather extremes with regard to food security in the Peruvian Altiplano. Regional Environmental Change 12, 489-505. http://dx.doi.org/10.1007/s10113-011-0246-5

Slaymaker, O., 2007. The potential contribution of geomorphology to tropical mountain development: the case of the MANRECUR project. Geomorphology 87, 90-100. http://dx.doi.org/10.1016/i.geomorph.2006.06.044

Stafford Smith, D.M., McKeon, G.M., Watson, I.W., Henry, B.K., Stone, G.S., Hall, W.B., Howden, S.M., 2007. Learning from episodes of degradation and recovery in variable Australian rangelands. Proceedings of the National Academy of Sciences of the United States of America 104, 20690-20695. http://www.pnas.org/cgi/content/abstract/104/52/20690

Stern, S.J., 1995. The variety and ambiguity of native Andean intervention in European colonial markets, in: Larson, B., Harris, O., Tandeter, E. (Eds.), Ethnicity, markets, and migration in the Andes: at the crossroads of history and anthropology. Duke University Press, Durham, USA, pp. 73-100.

Sundstrom, S.M., Angeler, D.G., Garmestani, A.S., García, J.H., Allen, C.R., 2014. Transdisciplinary application of cross-scale resilience. Sustainability 6, 6925-6948. http://dx.doi.org/10.3390/su6106925

Thompson, P.B., 2008. Agrarian philosophy and ecological ethics. Science and Engineering Ethics 14 527-544. http://dx.doi.org/10.1007/s11948-008-9094-1

Turner II, B.L., Kasperson, R.E., Matson, P.A., McCarthy, J.J., Corell, R.W., Christensen, L., Eckley, N., Kasperson, J.X., Luers, A., Martello, M.L., Polsky, C., Pulsipher, A., Schiller, A., 2003. A framework for vulnerability analysis in sustainability science. Proceedings of the National Academy of Sciences of the United States of America 100, 8074-8079. http://dx.doi.org/10.1073/pnas.1231335100

van Apeldoorn, D.F., Kok, K., Sonneveld, M.P.W., Veldkamp, T.A., 2011. Panarchy rules: rethinking resilience of agroecosystems, evidence from dutch dairy-farming. Ecology and Society 16, 39. URL: http://www.ecologyandsociety.org/vol16/iss31/art39/

Vassas-Toral, A., 2011. Ruralité et agriculture au prisme des mobilités spatiales. L'Altiplano Sud de Bolivie à I'heure du boom de la quinoa. Université Paul Valéry - Montpellier III, Montpellier, France, 345 p. + annexes. https://tel.archives-ouvertes.fr/tel-00668162/

Vassas-Toral, A., 2015a. Movilidades de los productores de quinua y dinámicas territoriales en el Altiplano Sur de Bolivia, in: Cruz, P., Joffre, R., Thierry, W. (Eds.), Racionalidades campesinas en los Andes del Sur: reflexiones en torno al cultivo de la quinua y otros vegetales andinos.

Vassas-Toral, A., 2015b. Movilidades, recursos de tierra y sistema de producción agrícola en el Altiplano Sur de Bolivia, in: Cruz, P., Joffre, R., Thierry, W. (Eds.), Racionalidades campesinas en los Andes del Sur: reflexiones en torno al cultivo de la quinua y otros vegetales andinos. EdiUNJU, Universidad Nacional de Jujuy, Jujuy, Argentina, pp. 281-321. 
Vassas-Toral, A., 2015c. Partir et cultiver: essor de la quinoa, mobilités et recompositions rurales en Bolivie. IRD Éditions, Marseille, France.

Vieira-Pak, M., 2015. El auge de la quinua: visiones de futuro en el Altiplano Sur de Bolivia, in: Cruz, P., Joffre, R., Thierry, W. (Eds.), Racionalidades campesinas en los Andes del Sur: reflexiones en torno al cultivo de la quinua y otros vegetales andinos. EdiUNJU, Universidad Nacional de Jujuy, Jujuy, Argentina, pp. 323-353.

Vollan, B., Ostrom, E., 2010. Cooperation and the commons. Science 330, 923-924. http://dx.doi.org/10.1126/science.1198349

Vucetich, J.A., Nelson, M.P., 2010. Sustainability: virtuous or vulgar? BioScience 60, 539-544. http://dx.doi.org/10.1525/bio.2010.60.7.9

Walker, B.H., Salt, D.A., 2006. Resilience thinking: sustaining ecosystems and people in a changing world. Island Press, Washington DC, USA.

Walsh-Dilley, M., 2013. Negotiating hybridity in highland Bolivia: indigenous moral economy and the expanding market for quinoa. The Journal of Peasant Studies 40, 659-682. http://dx.doi.org/10.1080/03066150.2013.825770

Westley, F., 2002. The devil in the dynamics: adaptive management on the front lines, in: Gunderson, L.H., Holling, C.S. (Eds.), Panarchy: understanding transformations in human and natural systems. Island Press, Washington DC, USA, pp. 333-360.

Winkel, T., Alvarez-Flores, R., Bertero, D., Cruz, P., Del Castillo, C., Joffre, R., Peredo Parada, S., agricultural sustainability in the Andean highlands. Idesia (Chile) 32, 95-100. http://dx.doi.org/10.4067/S0718-34292014000400012

Winkel, T., Alvarez-Flores, R.A., Bommel, P., Bourliaud, J., Chevarria Lazo, M., Cortes, G., Cruz, P., Del Castillo, C., Gasselin, P., Joffre, R., Léger, F., Nina Laura, J.P., Rambal, S., Rivière, G., Tichit, M., Tourrand, J.F., Vassas-Toral, A., Vieira-Pak, M., 2015. The southern altiplano of Bolivia, in: Bazile, D., Bertero, D., Nieto, C. (Eds.), State of the art report on quinoa around the world in 2013. FAO/Cirad, Santiago, Chile, pp. 362-377. URL: http://www.fao.org/363/ai4042e.pdf

Winkel, T., Bertero, H.D., Bommel, P., Chevarría Lazo, M., Cortes, G., Gasselin, P., Geerts, S., Joffre, R., Léger, F., Martinez Avisa, B., Rambal, S., Rivière, G., Tichit, M., Tourrand, J.F., Vassas-Toral, A., Vacher, J.J., Vieira-Pak, M., 2012. The sustainability of quinoa production in southern Bolivia: from misrepresentations to questionable solutions. Comments on Jacobsen (2011, J. Agron. Crop Sci. 197: 390-399). Journal of Agronomy and Crop Science 198, 314-319. http://dx.doi.org/10.1111/j.1439-037X.2012.00506.x

Winkel, T., Méthy, M., Thénot, F., 2002. Radiation-use efficiency, chlorophyll fluorescence and reflectance indices, associated with ontogenic changes in water-limited Chenopodium quinoa leaves. Photosynthetica 40, 227-232. http://dx.doi.org/10.1023/A:1021345724248

Young, O.R., 2010. Institutional dynamics: resilience, vulnerability and adaptation in environmental and resource regimes. Global Environmental Change 20, 378-385.

http://dx.doi.org/10.1016/j.gloenvcha.2009.10.001 
Zimmerer, K.S., 2013. The compatibility of agricultural intensification in a global hotspot of smallholder 860 agrobiodiversity (Bolivia). Proceedings of the National Academy of Sciences of the United States of America 110, 2769-2774. http://dx.doi.org/10.1073/pnas.1216294110

862 


\section{FIGURE CAPTIONS}

Fig. 1. Stylized representations of an adaptive loop (A) and a panarchy (B) showing "revolt" and 866 "remember" connections (adapted from Panarchy, Gunderson \& Holling, eds. 2002)

Fig. 2. Cropland expansion in the southern Bolivian altiplano from 1963 to 2006. (A) Palaya community. (B) Altitudinal distribution of total cropland area in 6 communities of the southern Bolivian Altiplano.

Fig. 3. Adaptive loops for the social subsystem $(A)$, household subsystem of quinoa growers $(B)$, and territorial subsystem $(C)$ in the southern Bolivian Altiplano.

872 Fig. 4. Quinoa panarchy in the southern Bolivian Altiplano from the 1970's $(A)$ to the present $(B)$. Dotted lines connect the relative positions of the adaptive loops of household economy (E), territorial land resources $(\mathrm{T})$, and social regulations $(\mathrm{S})$ in each time period. Black arrows in $(B)$ indicate changing alternatives in household economy.

876

\section{SUPPLEMENTARY MATERIAL CAPTIONS}

878 Supplementary Material A. The quinoa crop cycle in the southern altiplano of Bolivia.

Supplementary Material B. Mobility and migration among quinoa growers.

880 Supplementary Material C. Localisation and cropland area in six communities of the southern altiplano of Bolivia from 1963 to the 2000's.

Supplementary Material D. The Vulnerability Scoping Diagram. 


\section{FIGURES}

884
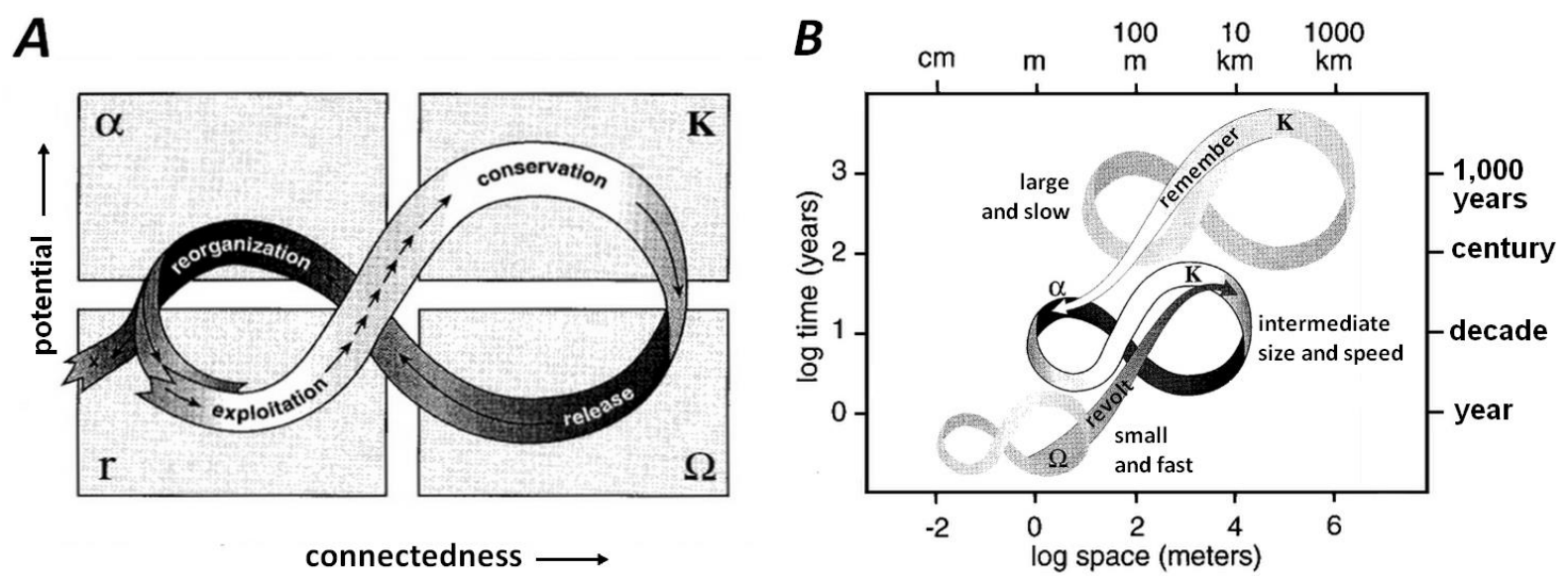

Fig. 1. Stylized representations of an adaptive loop (A) and a panarchy (B) showing "revolt" and "remember" connections (adapted from Panarchy, Gunderson \& Holling, eds. 2002).

890

892 


\section{FIGURES}

894
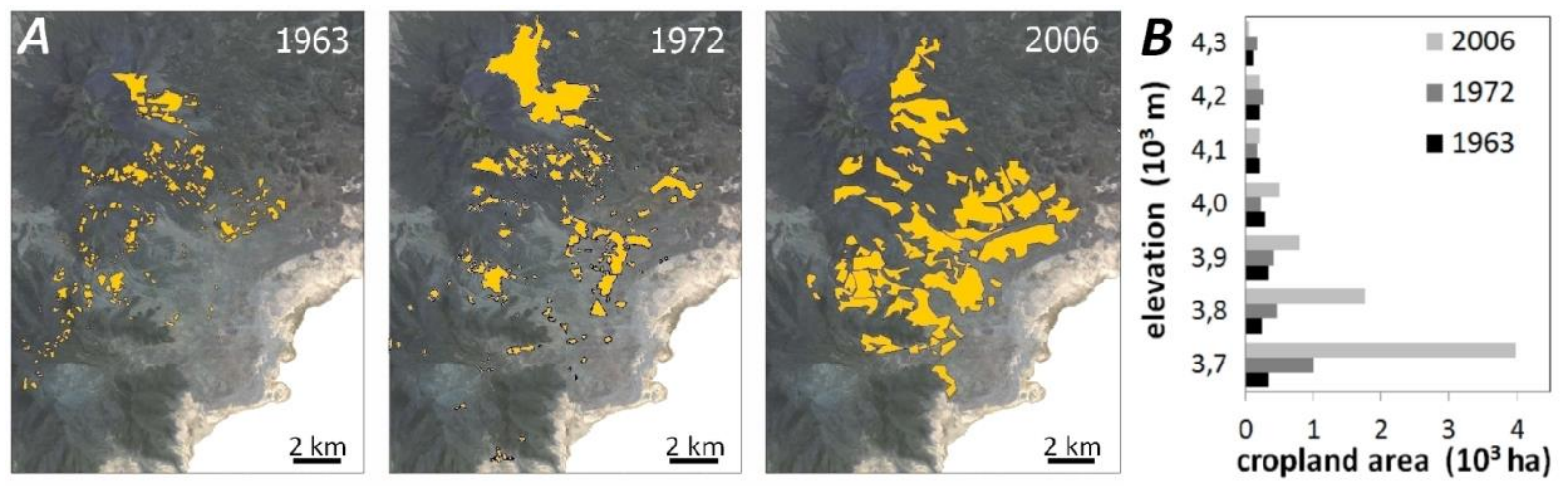

896 Fig. 2. Cropland expansion in the southern Bolivian altiplano from 1963 to 2006. (A) Palaya community. (B) Altitudinal distribution of total cropland area in 6 communities of the southern Bolivian 898 Altiplano. 
A

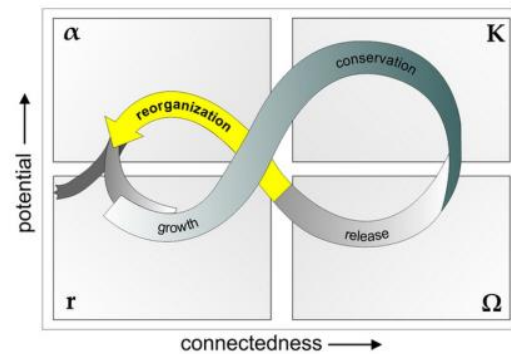

B

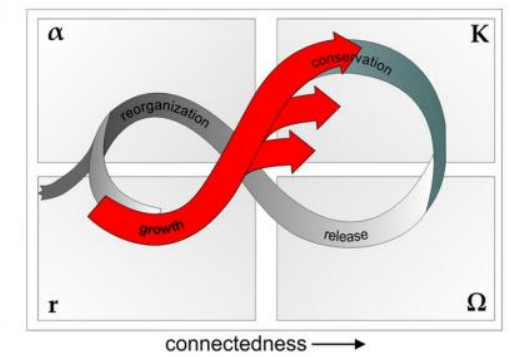

C

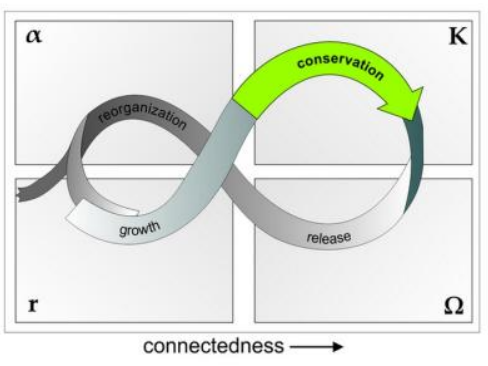

Fig. 3. Adaptive loops for the social subsystem $(A)$, household subsystem of quinoa growers $(B)$, and territorial subsystem $(C)$ in the southern Bolivian Altiplano. 


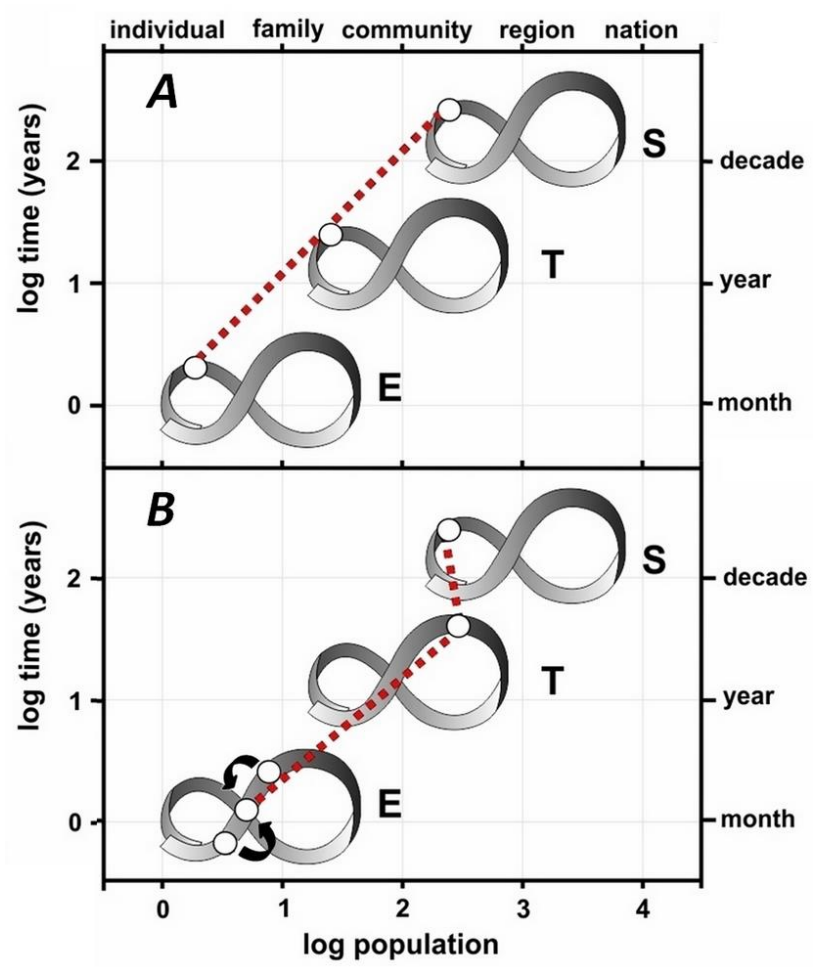

914 Fig. 4. Quinoa panarchy in the southern Bolivian Altiplano from the 1970's $(A)$ to the present $(B)$. Dotted lines connect the relative positions of the adaptive loops of household economy $(E)$, territorial 916 land resources $(\mathrm{T})$, and social regulations $(\mathrm{S})$ in each time period. Black arrows in $(B)$ indicate changing alternatives in household economy. 


\section{SUPPLEMENTARY MATERIAL}

Supplementary Material A. The quinoa crop cycle in the southern altiplano of Bolivia

Cultivation in that region has to cope with two major climatic constraints: a large frost period from April to October and a short rainy season between December and March. In fact, frost events may occur even during the rainy season, and the mean annual rainfall (lower than $250 \mathrm{~mm}$ ) does not cover the water requirements of a complete quinoa crop cycle. Thus, the quinoa crop cycle necessarily takes place over a two year period including a long period of plowed fallow with bare soil.

The crop calendar begins in Year 1 with the plowing of the land area planned to be harvested in Year 2. Plowing is done in January-February in order to facilitate rainfall infiltration and refilling of the soil water reserve. Nowadays, in the plains, this work is most often mechanized. During the austral in the subsurface soil layer in late August is sufficient for early sowing and seed germination (R. Joffre, unpublished data). Early sowing is advantageous as it allows for harvesting the crop before the MarchApril frost period, but it is also risky as the probability of a severe frost event damaging the quinoa seedlings in September-October is non-negligible. Quinoa seeds placed on the humid soil layer at a 10-20 cm depth germinate and fastly develop deep rooting (Alvarez-Flores et al., 2014a; AlvarezFlores et al., 2014b). The growing season lasts till March-April in Year 2 and the harvest has to be done before the main frost period (corresponding to the austral autumn-winter). During the postharvest period, a large part of the soil surface remains without any vegetation cover.

\begin{tabular}{|c|c|c|c|c|c|c|c|c|c|c|c|c|c|c|c|c|c|c|c|c|c|c|}
\hline & \multicolumn{10}{|c|}{ Year 1} & \multicolumn{12}{|c|}{ Year 2} \\
\hline Month & J F & $\mathrm{F} M$ & $A$ & $\mathrm{M}$ & J & $\mathrm{J}$ & $A \subseteq$ & $\mathrm{SO}$ & $\mathrm{N}$ & $\mathrm{D}$ & $\mathrm{J}$ & $\mathrm{F} N$ & M & A & M & $\mathrm{J}$ & J & $A$ & $S$ & O & $\mathrm{N}$ & D \\
\hline \multicolumn{23}{|l|}{ Climate } \\
\hline \multicolumn{23}{|l|}{ rainy season } \\
\hline \multicolumn{23}{|l|}{ main frost risks } \\
\hline Land use & \multicolumn{7}{|c|}{ plowed field } & \multicolumn{7}{|c|}{ cultivated field } & \multicolumn{8}{|c|}{ fallow } \\
\hline Vegetation & \multicolumn{8}{|c|}{ bare soil } & \multicolumn{6}{|c|}{$5-40 \%$} & \multicolumn{8}{|c|}{$<10 \%$} \\
\hline \multicolumn{23}{|l|}{ Cropping } \\
\hline \multicolumn{23}{|l|}{ plowing } \\
\hline \multicolumn{23}{|l|}{ sowing } \\
\hline \multicolumn{23}{|l|}{ crop growth } \\
\hline harvest & & & & & & & & & & & & & & & & & & & & & & \\
\hline
\end{tabular}

\section{Cited references}

Alvarez-Flores, R., Winkel, T., Degueldre, D., Del Castillo, C., Joffre, R. 2014a. Plant growth dynamics and root morphology of little-known species of Chenopodium from contrasted Andean habitats. Botany 92, 101-108. DOI: 10.1139/cjb-2013-0224.

Alvarez-Flores, R., Winkel, T., Nguyen-Thi-Truc, A., Joffre, R. 2014b. Root foraging capacity depends on root system architecture and ontogeny in seedlings of three Andean Chenopodium species. Plant Soil 380, 415-428. DOI 410.1007/s11104-11014-12105-x. 


\section{Supplementary Material B. Mobility and migration among quinoa growers}

This section shows patterns of mobility and pluriactivity among quinoa growers from the southern Altiplano of Bolivia. We considered several types of spatial mobilities: (i) the migration of individuals, defined as a temporary o permanent change of residence, including mobility of bi-residential migrants, (ii) the seasonal and circular mobility of migrants linked to the agricultural activity in their community.

A socioeconomic survey was conducted in two years $(2007,2008)$ on 149 households from 5 rural communities (San Juan, Chilalo, Otuyo, Candelaria, Palaya). Using interviews and livelihood stories, we reconstructed the residential and professional trajectories of 170 members of quinoa grower families (Vassas-Toral, 2011, 2015a, b, c). The results show (i) the extension of the migration area of 139 migrants people between 1934 and 2008 (Fig. B-1) and the diversity of the activities practised by male and female migrants in this period (Table B-1), (ii) two cases illustrating the individual trajectories of migrant people from these communities (Figs. B-2, 3), (iii) two cases illustrating the circular mobility trajectory linked to the agricultural activity (Fig. B-4, 5). To preserve confidentiality, the names of the interviewed people have been changed.

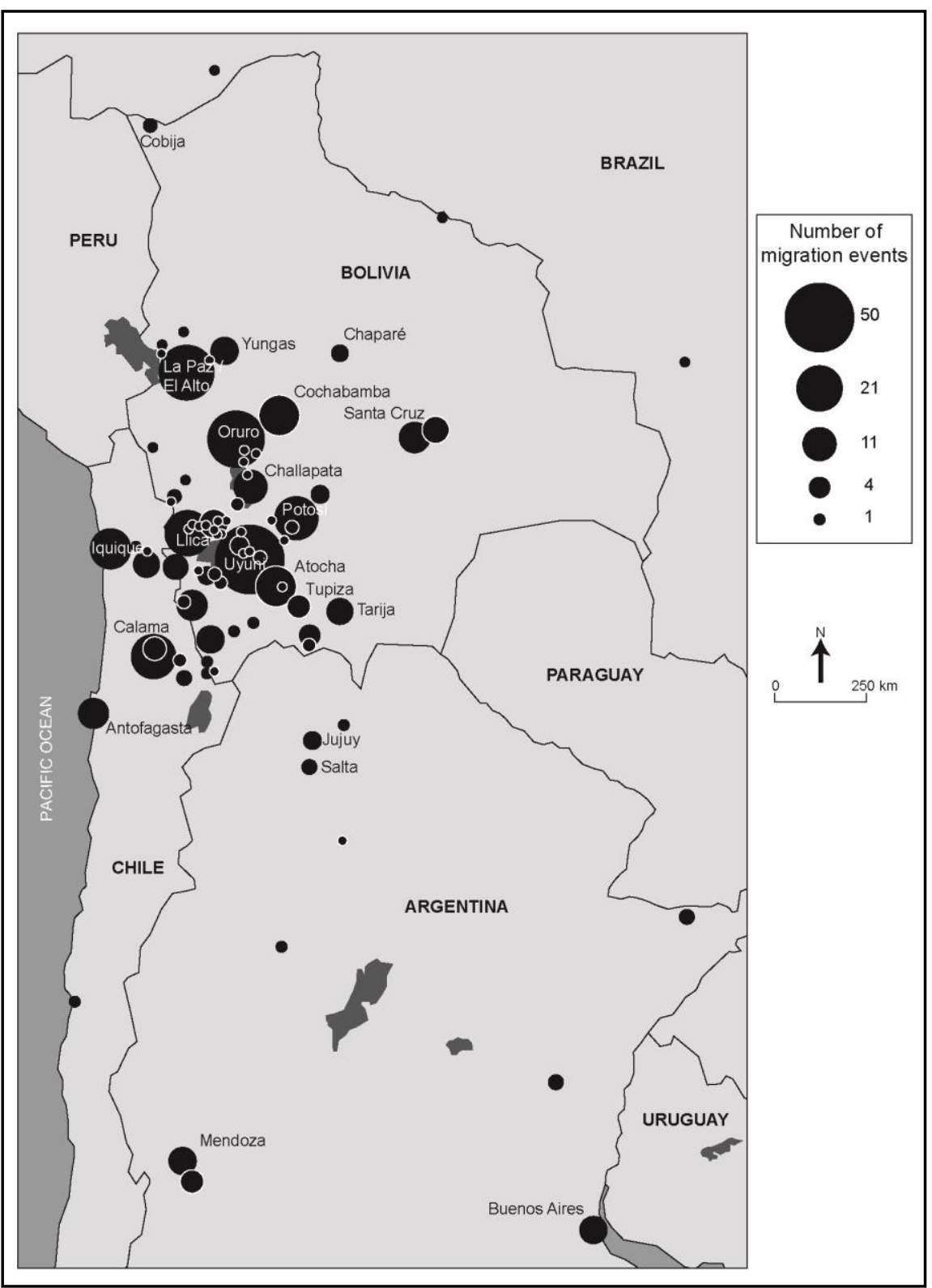

Fig. B-1. Extension of the migration area of 139 migrant people from 5 rural communities of the southern altiplano of Bolivia between 1934 and 2008.

Source: Interviews and livelihood stories, 20072008. Elaboration: A. Vassas-Toral and $\mathrm{S}$. Coursière. 
The mapping of the migrations of the 170 surveyed individuals (139 of them effectively migrating) reveals more than 400 events between 1934 and 2008, with urban and rural destinations in Bolivia, Chile and Argentina (Fig. B-1). In 2008, the main destinations of migration were big cities of Bolivia (La Paz, Oruro, Cochabamba) and Chile (Iquique). Table B-1 (below) shows the professional activities practised by 139 migrating people, differentiating male and female migrants (data are percent of interviewees who declared having practised the activity in at least one of their migrations):

\begin{tabular}{|c|c|c|c|c|}
\hline Economic sector & Division & Status and activity & Males (\%) & Females (\%) \\
\hline \multirow[t]{3}{*}{ primary } & \multirow[t]{2}{*}{ agriculture } & $\begin{array}{l}\text { informal sector employee: } \\
\text { farmhand, lumberer }\end{array}$ & 31 & 6 \\
\hline & & $\begin{array}{l}\text { self-employed worker: farmer, } \\
\text { tractor driver }\end{array}$ & 10 & 14 \\
\hline & mining & informal sector employee: miner & 44 & 0 \\
\hline \multirow[t]{4}{*}{ secondary } & \multirow[t]{2}{*}{$\begin{array}{l}\text { building } \\
\text { industry }\end{array}$} & $\begin{array}{l}\text { informal sector employee: } \\
\text { mason, carpenter, electrician }\end{array}$ & 29 & 0 \\
\hline & & $\begin{array}{l}\text { self-employed worker: foreman, } \\
\text { carpenter }\end{array}$ & 6 & 0 \\
\hline & \multirow[t]{2}{*}{$\begin{array}{l}\text { textile and } \\
\text { craft industries }\end{array}$} & $\begin{array}{l}\text { informal sector employee: } \\
\text { dressmaker, cabinetmaker, } \\
\text { brickwork, quinoa food } \\
\text { processing }\end{array}$ & 15 & 12 \\
\hline & & $\begin{array}{l}\text { self-employed worker: } \\
\text { dressmaker, baker, musician }\end{array}$ & 2 & 2 \\
\hline \multirow[t]{6}{*}{ tertiary } & \multirow[t]{2}{*}{$\begin{array}{l}\text { trade and } \\
\text { restaurant } \\
\text { industries }\end{array}$} & $\begin{array}{l}\text { informal sector employee: } \\
\text { grocer, ironmonger, caretaker, } \\
\text { waiter }\end{array}$ & 14 & 10 \\
\hline & & $\begin{array}{l}\text { self-employed worker: street } \\
\text { fooding, clothing trade, } \\
\text { restaurant }\end{array}$ & 14 & 37 \\
\hline & \multirow[t]{2}{*}{$\begin{array}{l}\text { car services } \\
\text { and } \\
\text { transportation }\end{array}$} & $\begin{array}{l}\text { informal sector employee: } \\
\text { mechanic, welder, minibus } \\
\text { driver, truck driver, railway } \\
\text { worker }\end{array}$ & 10 & 0 \\
\hline & & $\begin{array}{l}\text { self-employed worker: } \\
\text { mechanic, bodywork, welding, } \\
\text { minibus or truck business }\end{array}$ & 4 & 0 \\
\hline & domestic work & $\begin{array}{l}\text { informal sector employee: } \\
\text { daytime or fulltime servant }\end{array}$ & 0 & 50 \\
\hline & administration & $\begin{array}{l}\text { civil servant and assimilated } \\
\text { workers: nursing, rural } \\
\text { professor, policeman, } \\
\text { administrative officer }\end{array}$ & 16 & 0 \\
\hline
\end{tabular}


As illustrated below (Figs. B-2, 3), many people practise a temporary migration and a circulation between these different places and their community. These practices attest to the maintaining of personal links with the rural place of origin and a strong territorial anchoring, which facilitated the return of emigrated people to their communities during the period of quinoa expansion.

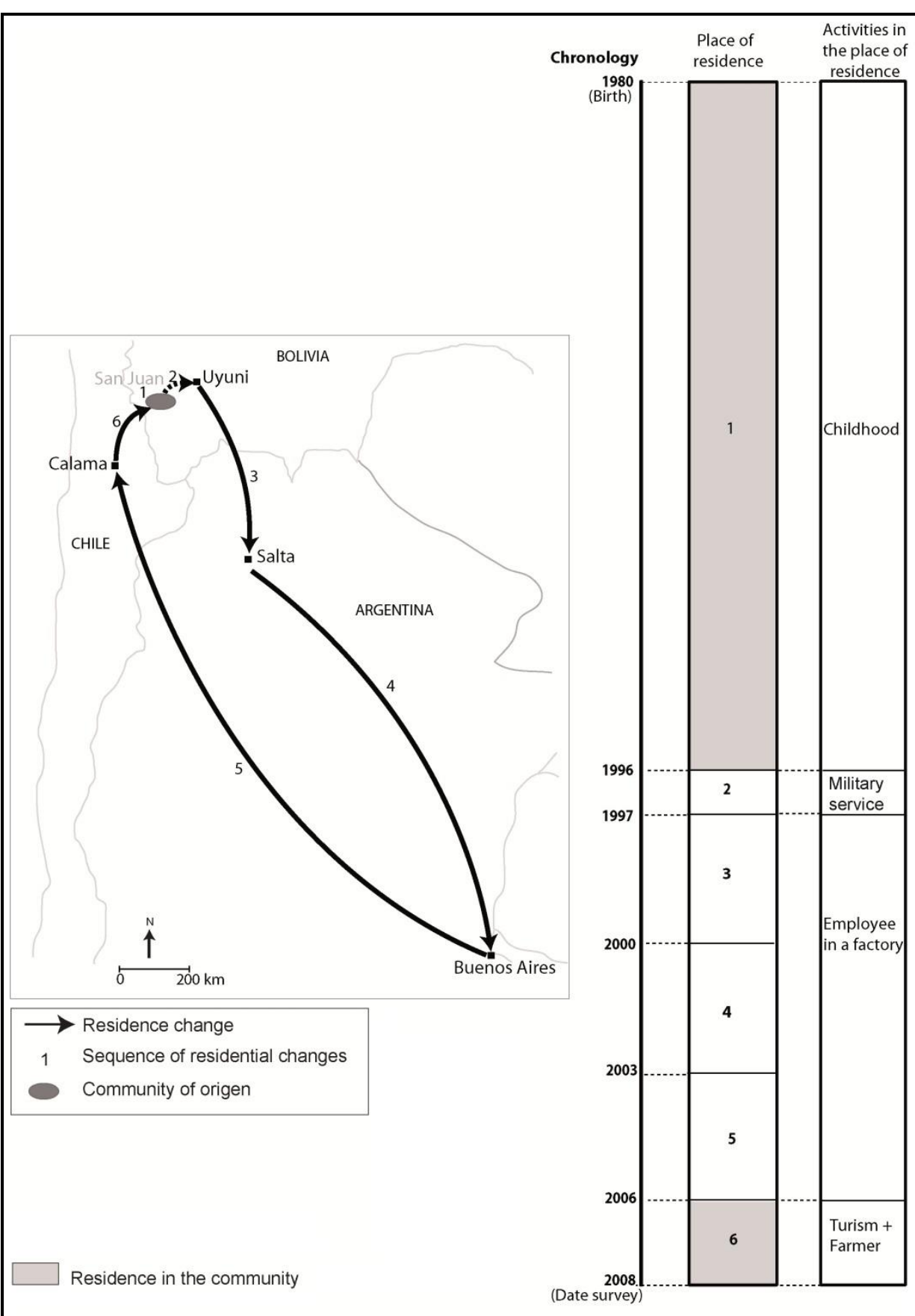

Fig. B-2.

Trajectory of residential mobility of Calixto, 28 y old, native of San Juan de Rosario, with residence in that community in 2008.

Source: VassasToral, interviews and livelihood stories, 20072008.

The trajectory of Calixto is typical of many young people who emigrated for a long time in Argentina and Chile, before returning in their community to produce quinoa. After 1 year in Uyuni to complete his military service, and 9 years as a factory worker in Salta, Buenos Aires and Calama 1008 (1996-2006), Calixto returned in 2006 to San Juan where he is now living from quinoa production and touristic activities. 


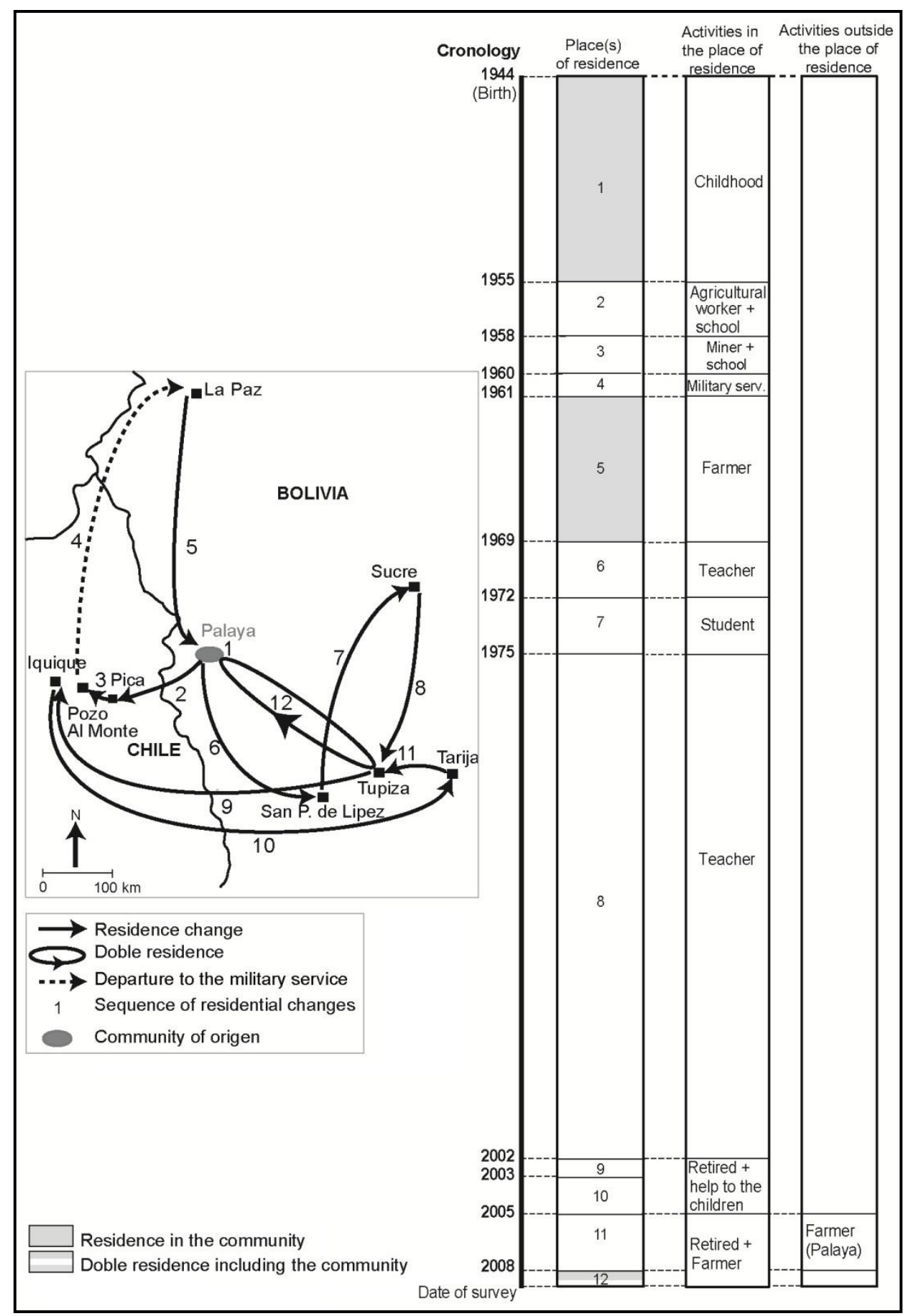

Fig. B-3.

Trajectory of residential mobility of Benedicto, $64 \mathrm{y}$ old, native from Palaya, with doble residence in Palaya and Tupiza in 2008 .

Source: VassasToral, interviews and livelihood stories, 20072008.

The migration trajectory of Benedicto is a complex one. He left alone the community of Palaya when he was 11 years old and, while going to the school, began working in Chile as an agricultural 1012 worker (peon) on the farm of a family member, and then as a miner. After completing his military service at the age of 17 in La Paz, he settled in Palaya for 9 years, cultivating his own lands. However 1014 the income of agriculture was insufficient for the family to live. So Benedicto decided to leave his comunity and began a long migratory trajectory as school profesor in urban centers: Sucre, Tupiza,

1016 Iquique, Tarija, and again Tupiza. In 2008 Benedicto retired. After 24 years of absence, he returned in his native community to dedicate himself to quinoa production on the lands of which he had retained 1018 usufruct. Like numerous quinoa growers in the southern Altiplano, he practices now a circular mobility with double residence between the countryside and the city. 


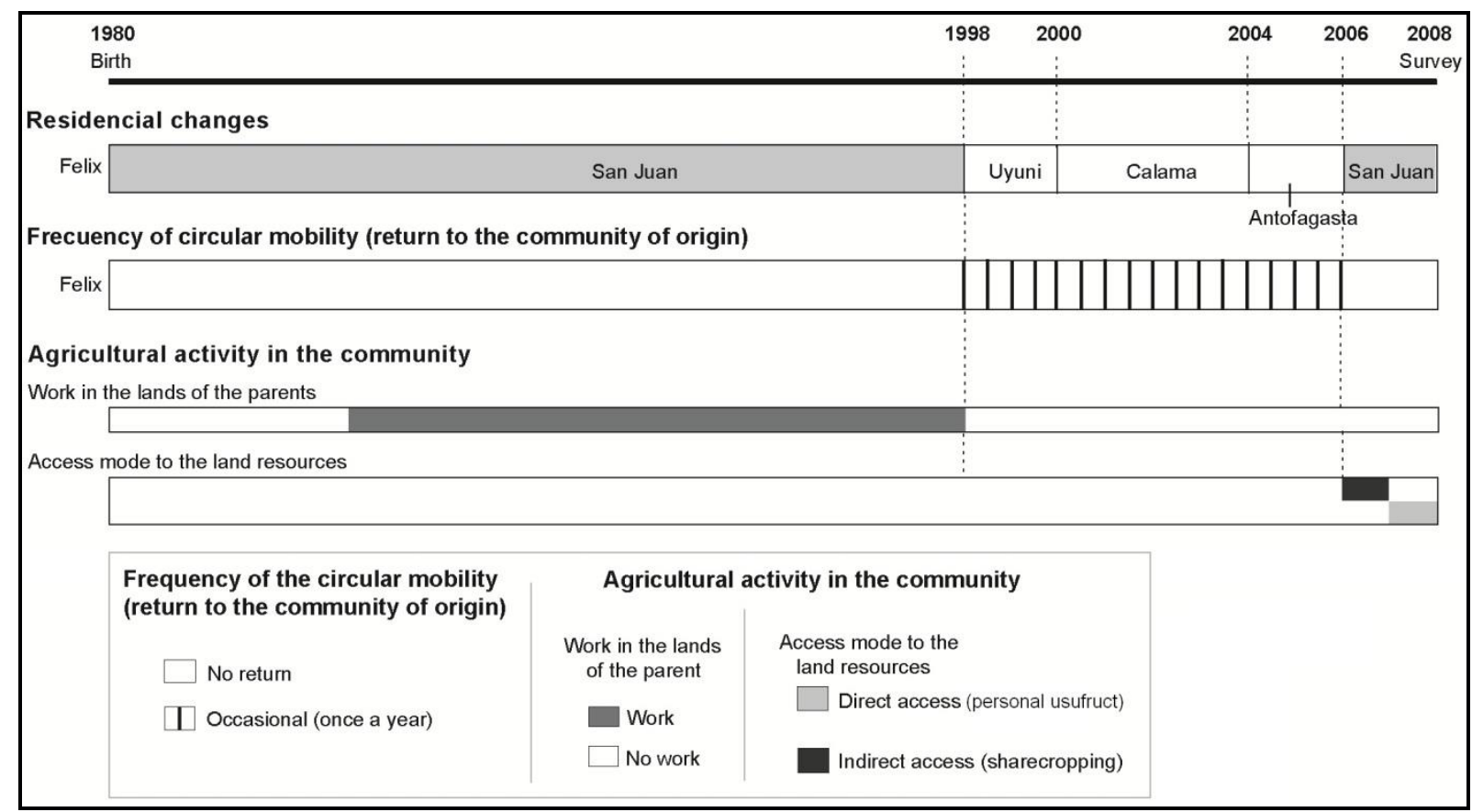

Fig. B-4. Trajectory of circular mobility linked with the agricultural activity of Felix, $28 \mathrm{y}$ old, native of San Juan de Rosario with residence in that community in 2008. Source: Vassas-Toral, interviews and livelihood stories, 2007-2008.

The trajectory of Felix is representative of numerous young people who contributed to the process of appropriation of lands in the southern altiplano. When he was 18 years old, Felix moved from his native comunity to Uyuni, then to Chile (Calama and Antofogasta) to work in the building sector. During eight years, he returned to his community every year to visit his parents. The link maintained with the community allowed him to move back in San Juan in 2006. However, having no direct access to cropland, Felix cultivated at first in sharecropping (al partir), before being able to clear some plots in the collective pasture lands, gradually becoming usufructuary of five hectares.

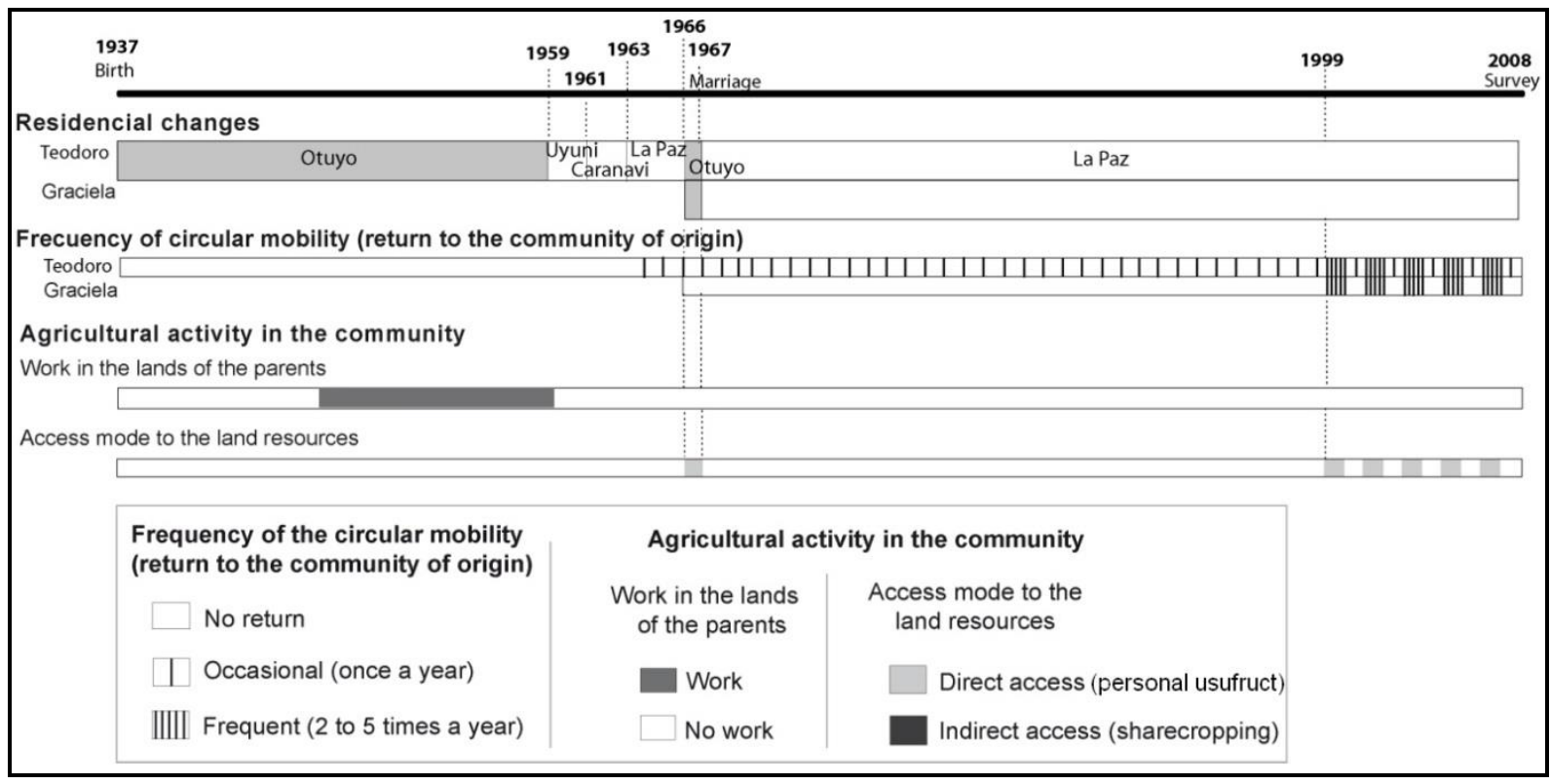

Fig. B-5. Trajectories of circular mobility linked with the agricultural activity of Teodoro and Graciela, both 71 y old, native of Otuyo with residence in La Paz in 2008. Source: Vassas-Toral, interviews and livelihood stories, 2007-2008. 
In 2008, Teodoro and Graciela were simultaneously residents in La Paz (the capital of Bolivia) and quinoa growers in their native community of Otuyo, more than $500 \mathrm{~km}$ away. Their trajectories show a continuous circular mobility between the city and the community during more than twenty years of migration (1963-1999). During this period, they didn't cultivate their lands any more but they 1040 returned once a year to their community to participate in local festivities, thus maintaining the right of usufruct of their lands. From 1999 on, when Teodoro and Graciela decided to cultivate their lands

1042 again to produce quinoa for trade, the frequency of their circular mobility increased. They return three or four times a year to cultivate their fields. The case of Teodoro and Graciela illustrates the 1044 emergence of "urban farmers" as a significant social group in the southern altiplano.

\section{Cited references}

Vassas-Toral, A., (2011) Ruralité et agriculture au prisme des mobilités spatiales. L'Altiplano Sud de

Bolivie à l'heure du boom de la quinoa. PhD thesis. Université Paul Valéry - Montpellier III, Montpellier, France, 345 p. + annexes. (in french)

Vassas-Toral, A., (2015a) Movilidades de los productores de quinua y dinámicas territoriales en el Altiplano Sur de Bolivia, in: Cruz, P., Joffre, R., Thierry, W. (Eds.), Racionalidades campesinas en los Andes del Sur: reflexiones en torno al cultivo de la quinua y otros vegetales andinos. EdiUNJU, Universidad Nacional de Jujuy, Jujuy, Argentina, pp. 231-280.

Vassas-Toral, A., (2015b) Movilidades, recursos de tierra y sistema de producción agrícola en el Altiplano Sur de Bolivia, in: Cruz, P., Joffre, R., Thierry, W. (Eds.), Racionalidades campesinas en los Andes del Sur: reflexiones en torno al cultivo de la quinua y otros vegetales andinos. EdiUNJU, Universidad Nacional de Jujuy, Jujuy, Argentina, pp. 281-321.

Vassas-Toral, A. (2015c) Partir et cultiver: essor de la quinoa, mobilités et recompositions rurales en Bolivie. IRD Éditions, Marseille, France. 
Supplementary Material C. Localisation and cropland area in six communities of the southern 1062 altiplano of Bolivia from 1963 to the 2000's.

1064 Latitude and longitude are in decimal degrees. Cropland areas were calculated using aerial photographs (1963), EROS satellite images (1972), and SPOT satellite images (2005-2008).

1066

\begin{tabular}{|c|c|c|c|c|}
\hline \multirow[b]{2}{*}{ Community } & \multirow[b]{2}{*}{ Altitude (m) } & \multicolumn{3}{|c|}{ Year } \\
\hline & & 1963 & 1972 & $2005-2008^{1}$ \\
\hline \multirow[t]{2}{*}{ Chacoma } & 3700 & 0.0 & 0.0 & 0.0 \\
\hline & 3750 & 20.1 & 46.6 & 450.0 \\
\hline latitude S & 3800 & 21.1 & 43.0 & 581.6 \\
\hline-19.71 & 3850 & 54.4 & 107.0 & 306.9 \\
\hline longitude W & 3900 & 69.3 & 79.5 & 166.5 \\
\hline \multirow[t]{5}{*}{-68.49} & 3950 & 109.0 & 124.1 & 180.3 \\
\hline & 4000 & 31.8 & 27.6 & 53.3 \\
\hline & 4050 & 26.0 & 21.6 & 22.9 \\
\hline & 4100 & 25.4 & 27.7 & 3.6 \\
\hline & 4150 & 0.0 & 5.0 & 0.0 \\
\hline Candelaria & 3700 & 21.5 & 108.8 & 870.1 \\
\hline \multirow[t]{2}{*}{ de Viluyo } & 3750 & 50.2 & 123.6 & 540.8 \\
\hline & 3800 & 7.0 & 41.8 & 104.4 \\
\hline latitude S & 3850 & 0.6 & 3.2 & 1.6 \\
\hline-19.68 & 3900 & 0.0 & 0.0 & 10.2 \\
\hline longitude W & 3950 & 0.0 & 0.0 & 9.8 \\
\hline \multirow[t]{3}{*}{-67.16} & 4000 & 0.0 & 0.0 & 7.4 \\
\hline & 4050 & 0.0 & 0.0 & 3.0 \\
\hline & 4100 & 0.0 & 0.0 & 0.0 \\
\hline \multirow[t]{2}{*}{ Capura } & 3700 & 0.0 & 0.0 & 0.0 \\
\hline & 3750 & 1.0 & 2.5 & 15.1 \\
\hline latitude S & 3800 & 14.9 & 40.7 & 247.6 \\
\hline-19.49 & 3850 & 2.6 & 4.6 & 0.8 \\
\hline longitude W & 3900 & 0.0 & 1.8 & 0.0 \\
\hline-67.28 & 3950 & 0.0 & 0.0 & 0.0 \\
\hline \multirow[t]{2}{*}{ Chilalo } & 3700 & 9.7 & 65.4 & 109.2 \\
\hline & 3750 & 16.0 & 14.4 & 1.6 \\
\hline latitude S & 3800 & 17.5 & 10.5 & 8.7 \\
\hline-19.8 & 3850 & 9.6 & 9.8 & 17.0 \\
\hline longitude W & 3900 & 16.0 & 5.2 & 8.4 \\
\hline \multirow[t]{6}{*}{-67.81} & 3950 & 12.4 & 6.2 & 3.0 \\
\hline & 4000 & 10.0 & 4.9 & 10.9 \\
\hline & 4050 & 5.2 & 1.8 & 6.5 \\
\hline & 4100 & 3.8 & 0.0 & 4.8 \\
\hline & 4150 & 9.2 & 1.2 & 0.0 \\
\hline & 4200 & 1.6 & 0.7 & 0.0 \\
\hline
\end{tabular}

${ }^{1} 2006$ in Chacoma and Palaya, 2008 in Candelaria de Viluyo, 2005 in Capura, Chilalo, and Otuyo. 


\begin{tabular}{|c|c|c|c|c|}
\hline & Altitude (m) & 1963 & 1972 & $2005-2008^{1}$ \\
\hline \multirow[t]{2}{*}{ Otuyo } & 3700 & 44.5 & 23.8 & 159.1 \\
\hline & 3750 & 35.6 & 94.8 & 328.5 \\
\hline latitude S & 3800 & 23.7 & 24.4 & 11.4 \\
\hline-19.59 & 3850 & 16.2 & 9.2 & 0.0 \\
\hline longitude W & 3900 & 8.0 & 1.0 & 0.0 \\
\hline \multirow[t]{2}{*}{-67.76} & 3950 & 2.2 & 0.0 & 0.0 \\
\hline & 4000 & 0.0 & 0.0 & 0.0 \\
\hline \multirow[t]{2}{*}{ Palaya } & 3700 & 14.2 & 242.9 & 713.8 \\
\hline & 3750 & 130.8 & 276.3 & 789.3 \\
\hline latitude S & 3800 & 38.1 & 104.2 & 293.7 \\
\hline-19.48 & 3850 & 29.8 & 66.5 & 197.2 \\
\hline longitude W & 3900 & 60.0 & 90.4 & 218.4 \\
\hline \multirow[t]{12}{*}{-68.08} & 3950 & 72.4 & 112.4 & 197.6 \\
\hline & 4000 & 106.2 & 76.8 & 191.2 \\
\hline & 4050 & 112.0 & 83.5 & 214.9 \\
\hline & 4100 & 89.2 & 63.5 & 112.1 \\
\hline & 4150 & 81.6 & 81.5 & 84.3 \\
\hline & 4200 & 100.2 & 158.7 & 108.2 \\
\hline & 4250 & 101.3 & 103.6 & 90.6 \\
\hline & 4300 & 61.3 & 99.1 & 30.5 \\
\hline & 4350 & 43.8 & 77.7 & 12.2 \\
\hline & 4400 & 18.4 & 46.7 & 6.4 \\
\hline & 4450 & 7.1 & 37.8 & 4.8 \\
\hline & 4500 & 2.6 & 76.5 & 6.1 \\
\hline
\end{tabular}


The socio-environmental assessment of quinoa production in the southern Altiplano of Bolivia may have different formulations, depending on the structural unit and the process of change under assessment. The Vulnerability Scoping Diagram in fig. D-1 synthesizes such an assessment focused on the rural community as the exposure unit, and on ecological degradation as the possible source of unsustainability for the considered community (an alternative object of assessment could have been, for example, the farming unit exposed to the market dynamics). The diagram specifies the components of exposure, sensitivity and adaptive capacity identified in the system. In the present case, the agrosystem is exposed to real or potential risks related to climate imprevisibility, land degradation, as well as increased social inequity or the possible desaffection of part of the quinoa consumers. The sensitivity to these risks refers to agrotechnical components, such as the management of natural resources and the crop yield. It depends also on social and economic components like land access or the dependence towards actors external to the community.

In this context, the mermbers of the community can show their adaptive capacity in different components: innovating in their individual and/or collective practices of land management, diversifying their markets, realizing pluri-activity with- or without temporary migration. The measures of these components can bring sustainability indicators. Examples of such indicators are: quantifying the expansion of the quinoa crop in the territory of the considered community, or characterizing the spatial and temporal dynamics of the mobility of the community members (Vassas-Toral, 2015a, b), or mapping frost risks at a geographical scale compatible with decision making for local crop management (Pouteau et al., 2011).

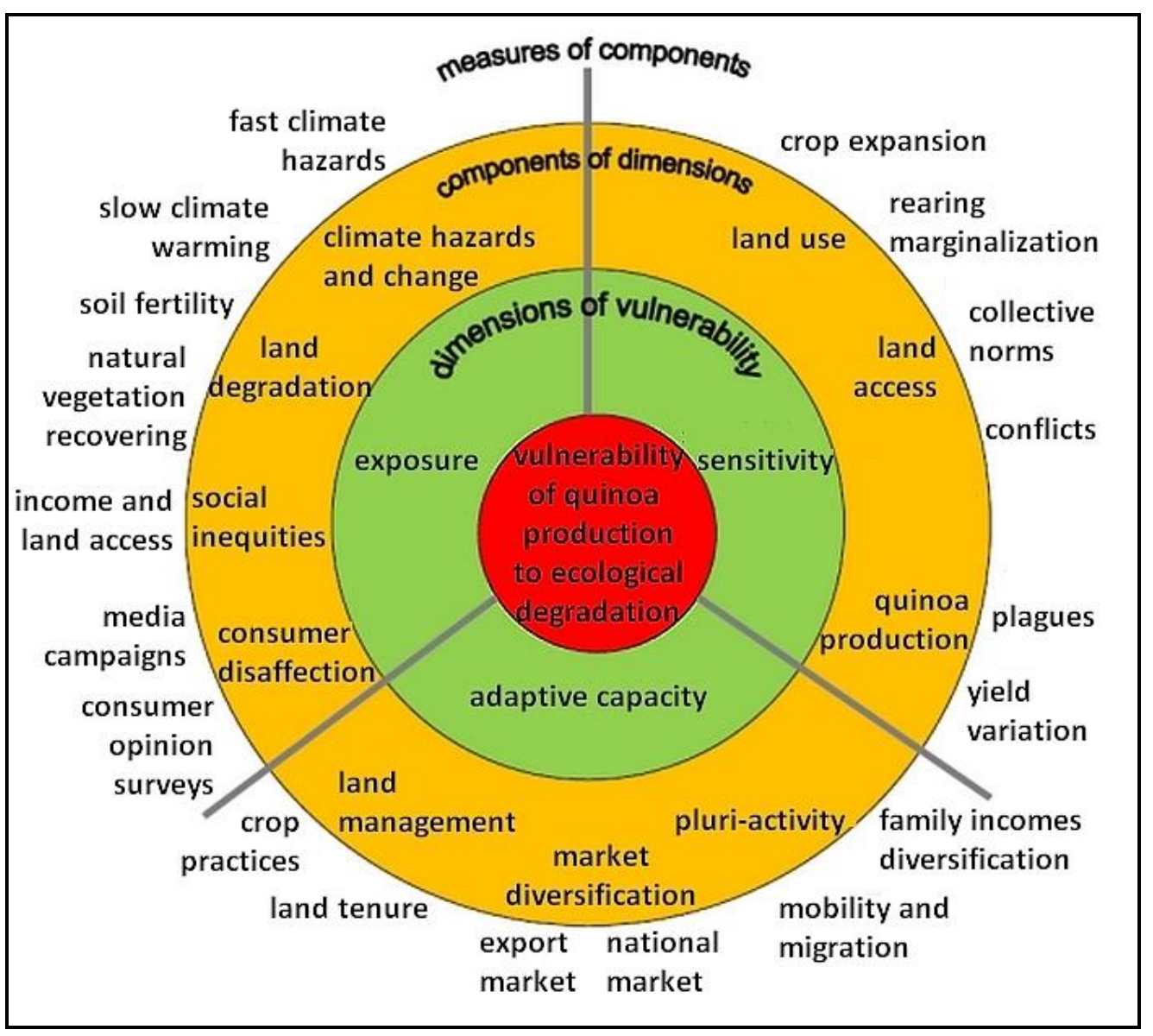

Fig. D-1. Vulnerability scoping diagram assessing the vulnerability to ecological degradation in the local quinoa production system. 


\section{Cited references}

1096

Pouteau, R., Rambal, S., Ratte, J.P., Gogé, F., Joffre, R., Winkel, T. (2011) Downscaling MODISderived maps using GIS and boosted regression trees: the case of frost occurrence over the arid Andean highlands of Bolivia. Remote Sensing of Environment 115, 117-129.

1098 Vassas-Toral, A., (2015a) Movilidades de los productores de quinua y dinámicas territoriales en el Altiplano Sur de Bolivia, in: Cruz, P., Joffre, R., Thierry, W. (Eds.), Racionalidades campesinas en los Andes del Sur: reflexiones en torno al cultivo de la quinua y otros vegetales andinos. EdiUNJU, Universidad Nacional de Jujuy, Jujuy, Argentina, pp. 231-280.

Vassas-Toral, A., (2015b) Movilidades, recursos de tierra y sistema de producción agrícola en el Altiplano Sur de Bolivia, in: Cruz, P., Joffre, R., Thierry, W. (Eds.), Racionalidades campesinas en los Andes del Sur: reflexiones en torno al cultivo de la quinua y otros vegetales andinos. EdiUNJU, Universidad Nacional de Jujuy, Jujuy, Argentina, pp. 281-321.

1106

1108 